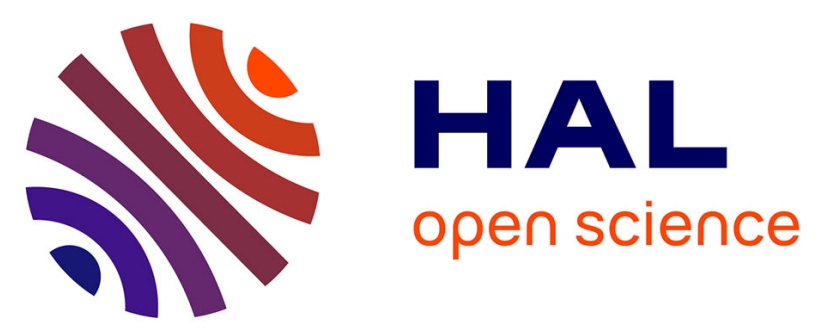

\title{
Noble gas solubilities in silicate melts: New experimental results and a comprehensive model of the effects of liquid composition, temperature and pressure
}

Giada Iacono-Marziano, Antonio Paonita, Andrea Rizzo, Bruno Scaillet, Fabrice Gaillard

\section{To cite this version:}

Giada Iacono-Marziano, Antonio Paonita, Andrea Rizzo, Bruno Scaillet, Fabrice Gaillard. Noble gas solubilities in silicate melts: New experimental results and a comprehensive model of the effects of liquid composition, temperature and pressure. Chemical Geology, 2010, 279 (3-4), pp.145-157. 10.1016/j.chemgeo.2010.10.017 . insu-00536899

\section{HAL Id: insu-00536899 \\ https://hal-insu.archives-ouvertes.fr/insu-00536899}

Submitted on 7 Dec 2010

HAL is a multi-disciplinary open access archive for the deposit and dissemination of scientific research documents, whether they are published or not. The documents may come from teaching and research institutions in France or abroad, or from public or private research centers.
L'archive ouverte pluridisciplinaire HAL, est destinée au dépôt et à la diffusion de documents scientifiques de niveau recherche, publiés ou non, émanant des établissements d'enseignement et de recherche français ou étrangers, des laboratoires publics ou privés. 
Noble gas solubilities in silicate melts: new experimental results and a comprehensive model of the effects of liquid composition, temperature and pressure.

\title{
Iacono-Marziano Giada ${ }^{1,2 *}$, Paonita Antonio ${ }^{1}$, Rizzo Andrea ${ }^{1}$, Scaillet Bruno ${ }^{2}$, Gaillard Fabrice $^{2}$
}

${ }^{1}$ Istituto Nazionale di Geofisica e Vulcanologia, Sezione di Palermo, Via Ugo La Malfa 153, 90146 Palermo, Italy.

2 Institut des Sciences de la Terre d'Orléans, Université d'Orléans/CNRS/Université François Rabelais-Tours (UMR 6113), 1A rue de la Férollerie, 45072 Orléans Cedex, France.

* Corresponding author

Giada.Iacono@cnrs-orleans.fr

\begin{abstract}
New experimental data of Ar and Ne solubility at pressures up to $360 \mathrm{MPa}$ in alkali-basaltic (Mt. Etna, Italy) and rhyolitic (Vulcano Island, Italy) melts are presented. Solubility experiments have been conducted in internally heated pressure vessels at $1200^{\circ} \mathrm{C}$ under nominally anhydrous conditions. Ar and Ne contents dissolved in the experimental glasses were then measured by quadrupole mass spectrometry. Over the pressure range investigated, Ar and Ne solubilities vary linearly with Ar and Ne pressures and can be described by Henry's constant $\left(\mathrm{k}_{\mathrm{Ar}, \mathrm{Ne}}=\mathrm{P}_{\mathrm{Ar}, \mathrm{Ne}} / x_{\mathrm{Ar}}\right.$, Ne, where $\mathrm{P}_{\mathrm{Ar}, \mathrm{Ne}}$ is the partial pressure of $\mathrm{Ar}$ or $\mathrm{Ne}$ and $x_{\mathrm{Ar}}$, Ne is the molar fraction of Ar or $\mathrm{Ne}$ in the melt) of $7.6 \pm 0.8^{*} 10^{5}$ and $1.9 \pm 0.4^{*} 10^{5} \mathrm{MPa}$, respectively for Ar and $\mathrm{Ne}$ in the basaltic melt and $1.5 \pm 0.2 * 10^{5}$ and $3.8 \pm 0.2 * 10^{4} \mathrm{MPa}$, respectively for $\mathrm{Ar}$ and $\mathrm{Ne}$ in the rhyolitic melt. In accordance with existing models, rhyolitic melts show higher noble gas solubilities than basaltic melts, Ne solubility being higher than that of $\mathrm{Ar}$ in a given composition. We propose a semiempirical model of noble gas (Ar, $\mathrm{Ne}$ and $\mathrm{He}$ ) solubility calibrated on a very large set of measurements in natural and synthetic silicate melts. The model expands the concept of ionic porosity in terms of porosity accessible for noble gas dissolution in melt, taking into account the large-scale structural effects of cations, as well as temperature and pressure. The model is valid over a wide range of temperatures $\left(800-1600^{\circ} \mathrm{C}\right.$ ), pressures (up to $3 \mathrm{GPa}$ ) and compositions, being useful for both geological and physico-chemical studies.
\end{abstract}

KEY WORDS: noble gases, magma, solubility, experimental study. 


\section{INTRODUCTION}

Noble gases are good markers of magma degassing processes, because they passively follow the evolution of the magma-vapor system driven by the major volatiles $\left(\mathrm{H}_{2} \mathrm{O}, \mathrm{CO}_{2}, \mathrm{SO}_{2}, \mathrm{H}_{2} \mathrm{~S}, \mathrm{Cl}\right.$ and F): they are preferentially partitioned into the vapor phase, without interacting with other species (Carroll and Webster 1994). This behavior is due to i) their chemically inert nature, ii) their trace concentration in magmas and iii) their low solubility in silicate melts (Carroll and Webster 1994). The modeling of noble gas degassing may therefore provide quantitative constraints on magma ascent from the source region to the surface, through crustal reservoirs (e.g. depths of magma storage; Caracausi et al. 2003). Such a quantitative modeling requires the knowledge of how noble gas solubilities vary with pressure, temperature and melt composition, including dissolved volatile species. Several experimental studies have investigated noble gas solubilities in silicate compositions at variable temperatures and pressures (Hayatsu and Waboso, 1985; Jambon et al., 1986; Lux, 1987; White et al., 1989; Carroll and Stolper, 1991, 1993; Broadhurst et al., 1992; Carroll et al., 1993; Shibata et al., 1996, 1998; Chamorro-Perez et al., 1996, 1998; Paonita et al., 2000; Schmidt and Keppler, 2002; Miyazaki et al., 2004; Marocchi and Toplis, 2005; Bouhifd and Jephcoat, 2006). However, the existing experimental database only partially covers the compositional range and the P-T conditions of magmas (Hayatsu and Waboso, 1985; Jambon et al., 1986; Lux, 1987; White et al., 1989; Carroll and Stolper, 1993; Paonita et al., 2000; Miyazaki et al., 2004).

The dissolution of noble gases in silicate melts is thought not to involve chemical interactions between the inert gas atoms and the surrounding melt: due to their inert nature, noble gas develop van der Waals interactions with silicate melts and seem to display a "physical solubility" in which the size of the noble atom plays a key role (Doremus, 1966; Shelby, 1976). Several experimental studies have indeed highlighted that the solubilities of noble gases decrease with increasing size of the gas atom (Jambon et al., 1986; Lux, 1987; Broadhurst et al., 1992) and are strongly dependent on melt composition (Lux, 1987; Carroll and Stolper, 1993; Shibata et al., 1998; Schmidt and Keppler, 2002). $\mathrm{SiO}_{2}$-rich compositions generally show higher noble gas solubilities than those depolymerized (Jambon et al., 1986; Lux, 1987; Carroll and Stolper, 1991, 1993; Shibata et al., 1998; Schmidt and Keppler, 2002). These features have suggested that the noble gas atoms may be accommodated in holes and free spaces of the melt on the basis on their atomic sizes. Rings of interconnected silicon tetrahedra have been proposed to work as solubility 
sites (Shackelford 1972). All noble gases have higher solubilities in silica-rich melts than in more mafic ones, as, in general, silicon and other tetrahedrally coordinated cations $\left(\mathrm{Al}, \mathrm{Fe}^{3+}, \mathrm{Ti}^{4+}\right)$ are network-formers, while $\mathrm{Na}^{+}, \mathrm{K}^{+}, \mathrm{Mg}^{2+}, \mathrm{Ca}^{2+}, \mathrm{Fe}^{2+}$ break the silicate polymers. In alumina-free melts, Shibata et al. (1998) found a direct relationship between noble gas solubility and degree of polymerization, the latter being expressed as $\mathrm{NBO} / \mathrm{T}$, namely the number of non-bridging oxygens per atom of tetrahedrally coordinated cations (Brawer and White, 1975). Noble gas solubility was also observed to be independent on the nature of network-modifier cations breaking the polymers (Shibata et al. 1998). In contrast, Marrocchi and Toplis (2005) observed a lack of correlation between Ar solubility and polymerization in Al-bearing melts. According to these authors, the number of the solubility sites for the noble gases, as well as their distribution, both vary as a function of the Al content of the liquid, owing to the different role of cations which act either as network modifiers or as charge balancers for Al.

Based on experimental studies, semi-empirical models have been developed to describe noble gas solubility in silicate melts. Shibata et al. (1998) calibrated the partial molar solubilities for the structural units with bridging oxygens and for those with non-bridging oxygens, the noble gas solubility being estimated as their weighted average. Marrocchi and Toplis (2005) considered the partial molar solubilities for Al-bearing tetrahedral units bonded to the main cations $\left(\mathrm{KAlO}_{2}\right.$, $\mathrm{NaAlO}_{2}, \mathrm{Ca}_{0.5} \mathrm{AlO}_{2}$ and $\mathrm{Mg}_{0.5} \mathrm{AlO}_{2}$ ), in addition to the partial molar solubilities of the main polymerized units (chains, sheets and three-dimensional network, called $\mathrm{Q}_{2}, \mathrm{Q}_{3}$ and $\mathrm{Q}_{4}$ respectively). Both models (Shibata et al. 1998; Marrocchi and Toplis 2005) are mathematically similar to those of Jambon (1987) and Chennaoui-Aoudjehane and Jambon (1990), except that they employ melt components having structural implications.

In accordance with the idea of physical interstitial dissolution, noble gas solubility has been found to correlate with several melt properties related to the free space in the silicate network: density (Lux, 1987; White et al., 1989), molar volume (Broadhurst et al., 1992) and ionic porosity (Carroll and Stolper 1993). Ionic porosity (IP) is defined as:

$I P=100\left(1-V_{\mathrm{ca}} / V_{L}\right)$

where $V_{\text {ca }}$ is the volume occupied by the constituent atoms (anions plus cations) in one gram of melt, and $V_{L}$ is the melt specific volume (Dowty, 1980; Fortier and Gilletti, 1989; Carroll and Stolper, 1993). For natural melts over a large compositional range (from basalt to rhyolite), IP shows an excellent correlation with the solubility of Ar and other noble gases (Carroll and 
Stolper 1993), however, such a correlation is substantially less apparent in simplified synthetic systems (e.g. CaO-MgO- $\mathrm{Al}_{2} \mathrm{O}_{3}-\mathrm{SiO}_{2}$ melts; Shibata et al., 1998; Marocchi and Toplis, 2005; Tournour and Shelby, 2008 a, b).

In this paper we present new experimental data of $\mathrm{Ar}$ and Ne solubilities as a function of pressure in both basaltic and rhyolitic melts. Then we propose a solubility model for noble gases $(\mathrm{He}, \mathrm{Ne}$ and Ar), based on a revised concept of melt ionic porosity and calibrated using a large set of measurements performed on both natural and synthetic silicate melts. In addition to the compositional effects, the model takes into account how temperature and pressure affect noble gas solubility. Although semi-empirical in nature, it has the advantage to broaden the compositional range encompassed by previous models (Carroll and Stolper, 1993; Shibata et al., 1998; Marrocchi and Toplis, 2005) and can be applied over a wider range of conditions (800$1600^{\circ} \mathrm{C}$ and $0.1-3000 \mathrm{MPa}$ ), being useful for both geological and physico-chemical studies. A spreadsheet is available (Electronic Annex) to calculate Ar, Ne and He solubility as a function of melt composition, temperature and pressure.

\section{MATERIALS AND METHODS}

\subsection{Starting material}

A basaltic lava of the 2002 Mt. Etna eruption was used as starting material. A homogeneous, bubble and crystal-free starting glass was obtained by grinding the lava and melting the powder at $1400^{\circ} \mathrm{C}$ and $1 \mathrm{~atm}$, for three hours. The starting glass composition is shown in Table 1. A rhyolitic obsidian from La Fossa flow, Vulcano Island, was also used as starting material (composition in Table 1), after having been degassed (glass chips few millimeters in size) for about $7 \mathrm{~h}$ at subsolidus temperature $\left(\sim 850^{\circ} \mathrm{C}\right)$ in a high vacuum line.

\subsection{Experimental apparatus and strategy}

The high-pressure experiments were conducted at the Institut des Sciences de la Terre d'Orléans (ISTO-France) in internally heated pressure vessels (IHPV) equipped with a rapid quench device (as described in Roux and Lefèvre, 1992). Experimental conditions are listed in Table 2. Investigated pressures ranged from $\sim 50$ to $\sim 360 \mathrm{MPa}$, in order to simulate magma conditions during the last stages of storage and ascent toward the surface. All experiments were conducted at a temperature of $1200 \pm 10^{\circ} \mathrm{C}$, which is higher than the liquidus temperature for both compositions 
at every investigated pressure. Powdered basaltic and rhyolitic glasses were loaded in $\mathrm{Au}_{80} \mathrm{Pd}_{20}$ open capsules, in order to minimize iron loss during the run, and then pressurized with pure Ar or $\mathrm{Ne}$ in the IHPV. After equilibration at $1200^{\circ} \mathrm{C}$, the samples were quenched to glasses at a rate of $\sim 100^{\circ} \mathrm{C} / \mathrm{s}$ (Di Carlo et al., 2006). We verified that an experimental time-length of two days was enough to achieve a homogeneous distribution of Ar in the experimental glasses (see Sec. 2.3). The use of powders allows the Ar penetrating through the grain interstices before melting, resulting in faster equilibration (Lux, 1987). Ne diffusivity has been shown to be higher than Ar (Lux, 1987, Behrens 2010a), hence we assume that the former also reached complete equilibrium between liquid and vapor phase in our experiments.

The redox conditions of the experiments were estimated to lie in the range FMQ- FMQ-3, on the basis of experimental conditions (i.e. total pressure and partial pressure of water) and intrinsic $\mathrm{fO}_{2}$ of the autoclave (Gaillard et al., 2003). No effort was made to control oxygen fugacity, since noble gas solubilities have been found to be almost independent on $\mathrm{fO}_{2}$ (Miyazaki et al., 2004)

\subsection{Analytical techniques}

The major element compositions of both starting and quenched glasses were determined with a Cameca SX-50 electron microprobe (EMP), using the following operating conditions: $15 \mathrm{kV}$ accelerating voltage, $7 \mathrm{nA}$ beam current, $10 \mathrm{~s}$ counting time on each spot, and 10-12 $\mu \mathrm{m}$ spot size. A Jeol GSM6400 scanning electron microscope (SEM) was employed to check for the occurrence of bubbles into the experimental glasses and to measure their minimum sizes.

${ }^{40} \mathrm{Ar}$ and ${ }^{20} \mathrm{Ne}$ concentrations dissolved in the experimental glasses were measured by a bulk extraction technique coupled to a quadrupole mass spectrometry at Istituto Nazionale di Geofisica e Vulcanologia, Sez. Palermo (Italy). The apparatus consisted of a load-lock, able to simultaneously load up to five samples, separated by a gate valve from the furnace. The latter was made of a quartz crucible, inserted in a tungsten filament basket equipped with a K-type thermocouple, in order to monitor the temperature during heating. The furnace was then connected to an ultra-high-vacuum line ( $\mathrm{UHV} ; \approx 10^{-13} \mathrm{MPa}$ ), equipped of a quadrupole mass spectrometer (QMS; Inficon transpector 2). Weighed amounts of experimental glasses were melted up to temperatures of $1100^{\circ} \mathrm{C}$ in UHV conditions, and degassed until all the dissolved volatiles were extracted, as indicated by the attainment of a plateau value in gas pressure (see below). The released gas mixture was purified through adsorption of all reactive species in $\mathrm{Zr}$-Al 
getters, while residual noble gases were continuously measured by the QMS, obtaining curves of growing $\mathrm{Ar}$ and $\mathrm{Ne}$ pressures as a function of time. During Ne analyses, a cold trap (made of charcoal cooled by liquid nitrogen) was also used in order to remove the minor amounts of ${ }^{40} \mathrm{Ar}$ present in the gas.

The blanks were performed before and after the analysis, without removing the rest of the analyzed samples, in order to confirm that the heated sample completely released the dissolved gases at $1100^{\circ} \mathrm{C}$. In both cases, $\mathrm{Ar}$ and Ne blanks at $1100^{\circ} \mathrm{C}$ were about $2 \times 10^{-8}$ and $2 \times 10^{-9} \mathrm{cc} \mathrm{STP}$ respectively. Three to ten analyses were performed for each sample, to verify their reproducibility. Analytical precision is estimated to be $\sim 15 \%$ on the basis of the analysis variability. The QMS was daily calibrated for both $\mathrm{Ar}$ and $\mathrm{Ne}$ in the pressure range of the analyzed samples, using air and a standard $1 \% \mathrm{vol}$ of $\mathrm{Ne}$ in a gas matrix of pure nitrogen.

Ar was also analyzed by EMP, using the following operating conditions: $15 \mathrm{kV}$ accelerating voltage, $25 \mathrm{nA}$ beam current, $100 \mathrm{~s}$ counting time on each spot. At least 10 points were analyzed in each glass. Ar contents were not quantitatively measured by EMP due to the lack of independent standards. Nevertheless, the electron microprobe allowed us to check for Ar homogeneity in the experimental samples, due to its very good spatial resolution (the spot size was $10-12 \mu \mathrm{m})$.

$\mathrm{H}_{2} \mathrm{O}$ concentrations in the quenched glasses were determined by transmission Fourier transform infrared spectroscopy (FTIR) on doubly polished glass chips. The utilized spectrometer was a Nicolet 760 Magna equipped with an IR microscope and a MCT detector. Absorption spectra were acquired in the range 2000-6000 $\mathrm{cm}^{-1}$ with 50-200 scans and a resolution of $4 \mathrm{~cm}^{-1}$, using a tungsten white light source with a $\mathrm{CaF}_{2}$ beam-splitter. For each sample 5 to 10 spots were analyzed to verify the homogeneity of the $\mathrm{H}_{2} \mathrm{O}$ content in the glass. Total water was calculated using the Lambert-Beer law from the absorbance of the fundamental $\mathrm{OH}$-streching vibration at about $3530 \mathrm{~cm}^{-1}$. The peak height was measured using a linear background correction. We used extinction coefficients from Fine and Stolper (1986) for the basaltic composition and from Newman et al. (1986) for the rhyolitic one. The thickness of the doubly polished glass sections was measured with a Mitutoyo digital micrometer and with the IR microscope gradation for each analyzed point (accuracy $\sim 5 \mu \mathrm{m}$ ). We measure the densities of the anhydrous and hydrous (up to $0.7 \mathrm{wt} \% \mathrm{H}_{2} \mathrm{O}$ ) basaltic and rhyolitic glasses using a Mettler-Toledo balance equipped with a density determination kit for solids. In total water calculations we used density values of 2.8 and 
$2.4 \mathrm{~g} / \mathrm{cm}^{3}$ for basaltic and rhyolitic glasses, respectively, after having tested that the error introduced by density variation with water content is negligible.

\section{EXPERIMENTAL RESULTS AND DISCUSSIONS}

The experimental glasses of basaltic composition were bubble and crystal-free, while those of rhyolitic composition were crystal-free, but contained variable proportions of bubbles, often heterogeneously distributed. This is most likely due to the fact that the starting materials were loaded in the form of powder: gravitational segregation of Ar bubbles (entrapped between powder grains) can occur in basaltic melts but not in rhyolitic ones, due to the significantly higher viscosity of the latter (Giordano et al., 2004). Optical microscopy and SEM imaging revealed absence of microlites and bubble sizes of $10-400 \mu \mathrm{m}$; prior to analysis by bulk extraction, the Ar-bearing rhyolitic glasses analyzed were therefore finely powdered to minimize the contribution of the bubbles. The same technique was however unsuited for Ne-bearing glasses because Ne loss of $\sim 20 \%$ was found to occur during fine grinding. Whenever the analyses were performed a few days after the fine grinding, measured Ne losses were substantially higher (up to $\sim 75 \%$ after 17 days). Bulk extraction of rhyolitic Ne-bearing glasses was therefore performed on selected bubble-free chips $\sim$ hundred microns in size. Atmospheric contribution to noble gas measurements due to $\mathrm{Ar}$ and $\mathrm{Ne}$ absorption on the powder grain has been checked to be negligible by analyzing both powder and glass chips of the basalt.

EMP analyses indicate that the compositions of the run products are similar to those of the starting materials, except for iron loss in basaltic compositions, which varies between 9-35\% of the initial iron content, depending on run duration. Nevertheless, iron contents were homogeneous in all the samples. EMP results also showed that the Ar is homogeneously distributed in both basaltic and rhyolitic glasses. The standard deviations of the EMP counts are substantially lower than those of the QMS analyses (2-6\%, versus 4-16 \%, Table 2 and Fig.1). It is worth noting that the Ar counts show a strong linear correlation with Ar contents as measured by QMS (Fig. 1). Such a correlation suggests that the chips of rhyolitic glass selected for the analyses were mostly bubble-free, or contained few bubbles that do not significantly affect the bulk extraction and subsequent QMS analyses: for a bubble 10 micron in size, which could elude optical investigations, we calculate a contribution to the measured amount of gas lower than $1.5 \%$ for Ar and $0.5 \%$ for $\mathrm{Ne}$. 
The QMS spectra (Fig.2) show that Ne is always released at temperatures lower than Ar. For rhyolitic glasses Ne degassing in UHV conditions starts once temperature begins to rise, ending at $\sim 200^{\circ} \mathrm{C}$, while Ar degassing mostly occurs between 100 and $650^{\circ} \mathrm{C}$. For basaltic glasses, both $\mathrm{Ne}$ and Ar degassing are more gradual: $\mathrm{Ne}$ is mainly released between 100 and $600^{\circ} \mathrm{C}$, while $\mathrm{Ar}$ degassing occurs between 300 and $1000^{\circ} \mathrm{C}$.

Table 2 presents $\mathrm{Ar}, \mathrm{Ne}$ and $\mathrm{H}_{2} \mathrm{O}$ contents dissolved in the glasses and their relative standard deviations. All analyzed samples showed homogeneous $\mathrm{H}_{2} \mathrm{O}$ contents between 0.10 and 0.72 $\mathrm{wt} \%$ for the basaltic glasses and between 0.06 and $0.31 \mathrm{wt} \%$ for the rhyolitic ones. Although water was not loaded in the capsules, it was probably present as an impurity in the gas pressure medium (Behrens 2010a). In addition, the presence of $\mathrm{H}_{2}$ in the autoclaves reduces the ferric iron of the sample into ferrous iron and generates $\mathrm{H}_{2} \mathrm{O}$ (Gaillard et al., 2003). From the amount of dissolved water, we used $\mathrm{H}_{2} \mathrm{O}$ solubility laws in basaltic (Lesne, 2008) and rhyolitic (Papale et al., 2006) melts to calculate the corresponding water fugacity in the gas phase, which was then converted into the partial pressure of water $\left(\mathrm{P}_{\mathrm{H} 2 \mathrm{O}}\right.$; Table 2) using a Modified Redlich-Kwong equation (see Nuccio and Paonita, 2000). The low amounts of $\mathrm{H}_{2} \mathrm{O}$ dissolved in our glasses imply low partial pressures of water, one to two orders of magnitude lower than those of noble gases (Table 2). Nonetheless, $\mathrm{P}_{\mathrm{H} 2 \mathrm{O}}$ was subtracted from the experimental pressure in order to obtain the real Ar or Ne pressure $\left(\mathrm{P}_{\mathrm{Ar}}, \mathrm{P}_{\mathrm{Ne}}\right)$ during the experiment. Figure 3 shows $\mathrm{Ar}$ and Ne solubilities in the basaltic and rhyolitic melts at $1200^{\circ} \mathrm{C}$ as a function of $\mathrm{P}_{\mathrm{Ar}}$ and $\mathrm{P}_{\mathrm{Ne}}$. Under the investigated conditions, Ar and Ne solubilities are linear with Ar and Ne pressures as already shown for Ar by previous experimental studies on different melt compositions (White et al., 1989; Carroll and Stolper, 1993). Therefore, to a first approximation, the solubilities of Ar and $\mathrm{Ne}$ can be described by the Henry's law and the Henry's constants could hence be calculated as:

$\mathrm{k}_{\mathrm{Ar}}=\mathrm{P}_{\mathrm{Ar}} / x_{\mathrm{Ar}}$

$\mathrm{k}_{\mathrm{Ne}}=\mathrm{P}_{\mathrm{Ne}} / x_{\mathrm{Ne}}$

where $x$ is noble gas concentration in melt, calculated as molar fraction on a simple oxide basis. For the basaltic melt, we estimate Henry's constants $\left(\mathrm{k}_{\mathrm{Ar}}, \mathrm{k}_{\mathrm{Ne}}\right)$ of $7.6 \pm 0.8 \times 10^{5}$ and $1.9 \pm 0.4 \times 10^{5}$ $\mathrm{MPa}$, respectively for $\mathrm{Ar}$ and $\mathrm{Ne}$, while for the rhyolitic melt, we obtain $1.5 \pm 0.2 \times 10^{5}$ and $3.8 \pm$ $0.2 \times 10^{4} \mathrm{MPa}$, respectively for Ar and Ne. At this point, however, we stress that such results are valid only over the low pressure range explored here. 
In Figure $3 \mathrm{~b}$ we also report Ne solubility data in vitreous albite at $1000^{\circ} \mathrm{C}$ (Roselieb et al., 1992), which are the only literature data of Ne solubility in silicate melts at pressure $>1 \mathrm{MPa}$. Figure $3 \mathrm{~b}$ shows that Ne solubility increases with the increasing polymerization of the melt, from the basaltic to the albitic composition, as already observed at pressures <1MPa (Jambon et al., 1986; Lux, 1987; Shibata et al., 1998).

Figure 4 compares our Ar solubility data (triangles) to previous experimental data in basaltic and rhyolitic compositions at pressures $<400 \mathrm{MPa}$ (squares, Carroll and Stolper, 1993). All compositions show linear trends as a function of pressure, but significant differences are apparent between the two rhyolitic compositions, as well as among the basaltic ones. The rhyolitic melt at $800-900^{\circ} \mathrm{C}$ (Carroll and Stolper, 1993) show Ar solubility substantially higher than our $\mathrm{SiO}_{2}$ poorer rhyolitic melt at $1200^{\circ} \mathrm{C}$. At $\sim 1200^{\circ} \mathrm{C}$, the basaltic andesite and mid-ocean ridge basalts (Carroll and Stolper, 1993) both exhibit higher Ar solubilities than the alkali (this study) and the olivine-tholeiitic (Carroll and Stolper, 1993) basalts. For these basaltic melts, the IP model (Carroll and Stolper, 1993) predicts at $1200^{\circ} \mathrm{C}$ important dissimilarities in solubility with melt composition (curves in Fig.4a), although the magnitude of the variations shown by the experimental data are not exactly reproduced. In the case of the rhyolitic melts, the IP model significantly underestimates $\mathrm{Ar}$ solubility at $800-900^{\circ} \mathrm{C}$ for the composition used by Carroll and Stolper (1993), since it predicts increasing Ar solubility with increasing temperature due to increasing IP (Fig. 4b). Experimental data between 500 and $900^{\circ} \mathrm{C}$ show, on the contrary, a slight inverse temperature dependence (Carroll and Stolper, 1993), which, together with the differences in the major element composition, could account for the different Ar solubility between the two rhyolites. A more refined modeling of both the compositional and temperature effects is therefore needed to account for the solubility differences among these basaltic and rhyolitic melts.

\section{MODELING NOBLE GAS SOLUBILITY}

\subsection{Limitations of the IP model}

Further serious limitations of the IP model also arise when we look at Ar solubility in simple synthetic silicate liquids at $0.1 \mathrm{MPa}$. Figure 5 shows Ar solubility data as a function of the ionic porosity of the melt of binary and ternary synthetic melts of Shibata et al. (1998), which were obtained either directly at $1600^{\circ} \mathrm{C}$, or extrapolated to this temperature by using the enthalpy of dissolution estimated in the same work. Recalling that Carroll and Stolper (1993) found a single linear relationship for all natural magmas, we observe a sharply different behavior in the case of 
simple synthetic melts. The binaries $\mathrm{Na}_{2} \mathrm{O}-\mathrm{SiO}_{2}$ (NS, filled triangles) and $\mathrm{CaO}-\mathrm{SiO}_{2}$ (CS, filled circles) fall along two different curves that converge on the pure silica end-member (black filled circle) and indicate distinct positions for the $\mathrm{CaO}$ and the $\mathrm{Na}_{2} \mathrm{O}$ end-members. Although less evident, the two different trends (for NS and CS binaries) are also appreciable when Ar solubilities are plotted versus $\mathrm{SiO}_{2}$ concentration (not shown). The $\mathrm{MgO}-\mathrm{SiO}_{2}$ sample (MS, filled square in Fig.5) also seems to suggest a diverse position of the $\mathrm{MgO}$ end-member. The ternary $\mathrm{CaO}-\mathrm{MgO}-\mathrm{SiO}_{2}$ melts (CMS, asterisks in Fig. 5) fall between the MS and the CS curves, while the $\mathrm{Na}_{2} \mathrm{O}-\mathrm{CaO}-\mathrm{SiO}_{2}$ melts (NCS, also represented by asterisks) fall between the CS and the NS curves. The ensemble of the previous results seems therefore to suggest that Ar solubility in CNMS melts changes as a function of melt composition, depending on the types of cations existing in the melt. In contrast, the Al-bearing synthetic melts (CNMAS, open squares in Fig. 5; Marrocchi and Toplis, 2005) delineate a single linear trend, and therefore display a different type of relation between solubility and IP than CNMS melts. Similarly to Ar, Tournour and Shelby (2008a) also observed significant discrepancies in the dependence of He solubility on ionic porosity in $\mathrm{Li}, \mathrm{K}$ or Na-bearing melts, so that different binary systems seem to depict different linear trends of solubility versus IP. These authors even found inverse relations between solubility and IP in both NS and KS melts when using a different set of ionic radii with respect to Carroll and Stolper (1993). Therefore, the effect of different cations on the melt porosity needs to be more accurately estimated.

In addition to composition, the effect of temperature is another factor that should be specifically taken into account in the IP model. In Figure 6, we show the solubility of Ar in several natural melt compositions as a function of ionic porosity, at $0.1 \mathrm{MPa}$ and variable temperatures (Hayatsu and Waboso, 1985; Jambon et al., 1986; Lux, 1987; Marrocchi and Toplis, 2005). The experiments at $1600^{\circ} \mathrm{C}$ define a single trend, while the experiments performed at lower temperatures are shifted towards lower Ar solubilities and ionic porosities, each melt composition describing its own linear trend. To account for this thermal effect, Marrocchi and Toplis (2005) recalculated all the IP of the melts at $1600^{\circ} \mathrm{C}$, with no regard to the real temperature of experiments, by using the partial molar volumes at $1600^{\circ} \mathrm{C}$ (Lange and Carmichael 1987) and the volumes of cations and oxygen predicted from Shannon and Prewitt (1969). For natural and simplified (CNMAS) melts, Ar solubility correlates substantially better with IP at $1600^{\circ} \mathrm{C}$ than with temperature-dependent IP, although some deviations from a simple correlation are still 
apparent (Marrocchi and Toplis, 2005). Moreover, the recalculation of Marrocchi and Toplis, (2005) does not predict any temperature dependence of Ar solubility. We therefore propose an alternative solubility model, which includes the effects of temperature and pressure on Ar solubility.

\subsection{New definition of ionic porosity}

The most significant modifications of our model concern the estimation of the IP of the melt on the basis of its composition, temperature and pressure. We chose to maintain the oxide components to describe the melt composition, but we estimate the volume that they occupy ( $V_{c a}$ in Eq. 1) in a different way. The limit of the concept of IP is that it does not account for variations in number of site and shape of the holes which may host noble gases. Recalling that classic IP model uses radii of ions in oxides to calculate the filled volume $V_{c a}$ (Carroll and Stolper, 1993), such estimation sounds oversimplified in light of the growing knowledge about the structural complexity of silicate melts. In fact, ions in melts could have different coordination and radius than in simple oxides, and, more importantly, the effect of any cation on noble gas solubility depends on its capability of modifying the available free space by forming, distorting or breaking the tetrahedra network (Paonita, 2005 and references therein). This means that every cation causes its own change of porosity in the melt, although this is only partially linked to its ionic radius in the corresponding oxide. On this basis, the concept of melt IP is still meaningful to describe noble gas solubility, since its mathematical formulation expresses the free space in the melt. Nevertheless, the values of the ionic radii estimated from the oxides could be no more appropriate to quantify the free space to allocate noble gas atoms. We should strictly speak about a "partial filled volume" for each cation oxide referring to the true occupied space. The IP would therefore represent the space readily available to accommodate noble gas atoms and is reformulated as:

$I P=100\left(1-\frac{1}{M V_{L}} \sum_{i}^{n} v_{i} x_{i}\right)$

where $M$ is the mass of one mole of melt in oxides, $V_{L}$ is the specific volume of the melt, $v_{i}$ and $x_{i}$ are respectively the partial molar filled volume and the molar fraction of each oxide $i$. We stress that the available IP should not be regarded as a space that can be wholly filled by 
the selected noble gas atoms, but it is just a proxy of it. We define the partial molar filled volume as:

$v_{i}=v_{\mathrm{ca}, i}+v_{\mathrm{s}, i}$

where $v_{\mathrm{ca}, i}$ is the ionic molar volume of an oxide compound, computed using the radii of its anions and cations (as in the classic IP model), and $v_{\mathrm{s}, i}$ is the contribution to the filled volume per oxide mole due to large-scale structural effects. The parameters $v_{\mathrm{s}, i}$ were calibrated by fitting measured solubilities; this means quantifying the space available to accommodate noble gas atoms and not the total free space of the melt. However, the conceptual meaning of the IP is not substantially changed.

We recall that, in the IP model (Carroll and Stolper, 1993; Nuccio and Paonita 2000), the noble gas solubility is expressed as:

$-\ln \left(k_{g}\right)=-\ln \left(f_{g} / x_{g}\right)=\alpha_{g} I P+\beta_{g}$

where $k_{g}$ is the solubility constant of the noble gas in the melt (calculated using oxide components), $f_{g}$ is the fugacity of noble gas, and $x_{g}$ is the amount of noble gas dissolved in the melt. Subscript "g" indicates the noble gas. $\alpha_{g}$ and $\beta_{g}$ are linear trend parameters specific to each noble gas and independent on the composition of the melt (Carroll and Stolper, 1993). At $0.1 \mathrm{MPa}$, the solubility constant is therefore an inverse measurement of the dissolved noble gas $\left(k_{g}=1 / x_{g}\right)$.

From Eqs. 5 and 6 we obtain the following general equation for noble gas solubility:

$-\ln \left(k_{g}\right)=\alpha_{g}\left[100-\frac{100}{M V_{L}}\left(\sum_{i}^{n} v_{c a, i} X_{i}+\sum_{i}^{n} v_{s, i} x_{i}\right)\right]+\beta_{g}$

Noteworthy, Eq.7 involves a non-linear relationship between $\ln \left(k_{g}\right)$ and oxide molar fractions (as in the classical IP model), in contrast to solubility models based on compositionally weighted average of oxide solubility (e.g. Jambon, 1987).

\subsection{Effects of pressure and temperature and general model formulation}

We have already discussed that the temperature effect on Ar solubility and IP is different for each melt composition (Fig.6). The increase in porosity with temperature computed by the IP model (Carroll and Stolper, 1993) is due to the thermal expansion of silicate melts, while the ionic volumes (Vca in Eq. 1) are temperature independent. The thermal expansion is a consequence of both the deformation of the Si-O-Si angles and increased vibration of the ionic bonds with 
temperature (Lange and Carmichael, 1987), yet it is also obvious that a large fraction of the increased volume is filled by the vibrating atoms. This implies that considering the filled volumes of oxides independent of temperature overestimates the thermal increase of IP.

The effect of pressure is somewhat opposite to that of temperature. Figure 7 shows Ar solubility data (as $-\ln \left[k_{g}\right]$ ) of selected melts run at $1600^{\circ} \mathrm{C}$ over a range of pressures: $\mathrm{Ar}$ solubility decreases linearly with pressure up to at least 2-3 GPa. At higher pressures (not shown in the figure), the data progressively diverge from the linear behavior, probably due to the fact that a threshold of dissolved concentration is reached (Guillot and Sarda, 2006). Such a behavior has been explained as reflecting saturation of available solubility sites (Schmidt and Keppler, 2002), but its quantitative modeling is beyond the aim of this work.

To account for the effective space that the thermal and/or decompressive expansion makes available to accommodate noble gas atoms, we have considered that the partial molar filled volumes vary as a function of temperature and pressure following:

$v_{i, T, P}=v_{\mathrm{ca}, i}{ }^{\circ}+v_{\mathrm{s}, i}{ }^{\circ}+\lambda_{i}\left(1 / \mathrm{T}-1 / \mathrm{T}^{\circ}\right)+\kappa_{i}\left(\mathrm{P}-\mathrm{P}^{\circ}\right)$

where $\kappa_{i}$ and $\lambda_{i}$ are the derivative of the partial filled volume for oxide with respect to pressure and reciprocal temperature respectively, and the superscript "o" refers to parameters at the reference temperature $\mathrm{T}^{\circ}$ and pressure $\mathrm{P}^{\circ}$. We tested that more complex dependences on $\mathrm{P}$ and $\mathrm{T}$ did not improved the model predictions, and maintained the simplest form represented by Eq.8. To improve model performance, we needed to add a quadratic compositional term $v_{\mathrm{q}, N a 2 O}$ $x^{2}{ }_{N a 2 O}$ to Eq.8 (subscript "q" means quadratic), for which similar thermal and baric dependencies are considered:

$v_{\mathrm{q}, T, P, N a 2 O}=v_{\mathrm{q}, N a 2 O}{ }^{\circ}+\lambda_{\mathrm{q}, N a 2 O}\left(1 / \mathrm{T}-1 / \mathrm{T}^{\circ}\right)+\kappa_{\mathrm{q}, N a 2 O}\left(\mathrm{P}-\mathrm{P}^{\circ}\right)$

Nonetheless, this term becomes important only for $\mathrm{Na}$ contents above those of natural melts $(>15-20 \mathrm{wt} \%)$ and can be neglected for geological purposes. From Eqs.7-9 and the classical formulation of the IP model (Eq.6) we therefore obtain the following model equation:

$-\ln \left(k_{g}\right)=\alpha_{g}\left[100-\frac{100}{M V_{L, T}}\left(\sum_{i}^{n} v_{T, P, i} X_{i}+v_{q, T, P, N a_{2} \mathrm{O}} X_{\mathrm{Na}_{2} \mathrm{O}}^{2}\right)\right]+\beta_{g}$

where the subscripts " $\mathrm{T}$ " and "P" indicate the parameters that are function of both temperature and pressure. Eqs.8-10 allow to calculate noble gas solubility, once the parameters $v_{\mathrm{s}, i}{ }^{\circ}, \kappa_{i}, \lambda_{i}$, $v_{\mathrm{q}, \mathrm{Na} 2 \mathrm{O}}{ }^{\circ}, \lambda_{\mathrm{q}, \mathrm{Na} 2 \mathrm{O}}, \kappa_{\mathrm{q}, \mathrm{Na} 2 \mathrm{O}}, \alpha_{g}$ and $\beta_{g}$ have been calibrated by regression on a set of experimental data of noble gas solubility. The specific volume of the melt $\left(V_{L}\right)$ was calculated by using the 
model of Lange and Carmichael (1987), which accounts for the oxide contents of the melt, without considering any structural effect.

\subsection{Results and discussion of the model}

In calibrating the model, we considered partial molar filled volumes for the nine main oxides $\left(\mathrm{SiO}_{2}, \mathrm{Al}_{2} \mathrm{O}_{3}, \mathrm{TiO}_{2}, \mathrm{FeO}, \mathrm{Fe}_{2} \mathrm{O}_{3}, \mathrm{MgO}, \mathrm{CaO}, \mathrm{Na}_{2} \mathrm{O}, \mathrm{K}_{2} \mathrm{O}\right)$. We used our data and available literature data of $\mathrm{He}, \mathrm{Ne}$ and $\mathrm{Ar}$ (Table 3). In the case of Ar, the available literature data cover a large compositional range, both for synthetic and natural silicate melts. The selected dataset consists of about 230 measurements of solubility between $800^{\circ} \mathrm{C}$ and $1600^{\circ} \mathrm{C}$, and $0.1 \mathrm{MPa}$ and $3 \mathrm{GPa}$. We did not include very high pressure data from Chamorro-Perez et al. (1996, 1998), Schmidt and Keppler (2002) and Bouhifd et al. (2008), due to the progressive departure from the linear relation $\ln (k)$ vs. IP at pressure higher than 2.5-3 GPa. Both $\mathrm{He}$ and $\mathrm{Ne}$ datasets are less comprehensive than those of Ar and include about 100 measurements of solubility each. The data span in composition from synthetic to natural silicate melts (acid to basic), within the temperature range of $900-1600^{\circ} \mathrm{C}$. Most of the data were obtained at 0.1 to $1 \mathrm{MPa}$ of $\mathrm{Ne}$ or $\mathrm{He}$ pressure, with the exception of our data and $\mathrm{Ne}$ solubilities measured in albite melt at 10-500 MPa (Roselieb et al. 1992).

We used Eq.10 to calibrate all the parameters by regression of experimentally measured solubilities. We remind that $k_{g}$ is the measured solubility to be used in Eq.10, expressed as $f_{g}$ $/ x_{g}$ (Eq. 6). While the values of $k_{g}$ are directly available for experiments performed at $0.1 \mathrm{MPa}$, for experiments performed at higher pressures, the values of $k_{g}$ were obtained from measured noble gas concentrations $\left(x_{g}\right)$ and fugacities $\left(f_{g}\right)$ calculated at the experimental T and $\mathrm{P}$ from the equation of state of Nuccio and Paonita (2001). The parameters $\alpha_{g}$ and $\beta_{g}$ where calibrated for each noble gas, as in the classical IP model (Carroll and Stolper 1993). The need of calibrating the parameters $v_{\mathrm{s}, i^{\circ}}, \kappa_{i}, \lambda_{i}, v_{\mathrm{q}, \mathrm{Na} 2 \mathrm{O}^{\circ}}, \lambda_{\mathrm{q}, \mathrm{Na} 2 \mathrm{O}}$, and $\kappa_{\mathrm{q}, \mathrm{Na} 2 \mathrm{O}}$, together with $\alpha_{\mathrm{g}}$ and $\beta_{\mathrm{g}}$ values, required the use of a routine of non-linear multiple regression.

Various attempts were performed in order to reduce the number of fitted parameters. We chose to set $\lambda_{\mathrm{TiO} 2}, \lambda_{\mathrm{FeO}}$ and $\kappa_{\mathrm{TiO} 2}$ to zero, as their incorporation caused no practical improvement of the regression. We coupled the $\mathrm{T}$ and $\mathrm{P}$ dependence of $\mathrm{Mg}$ and $\mathrm{Ca}$, as well as $\mathrm{P}$ dependence of iron, that involves the conditions $\lambda_{\mathrm{CaO}}=\lambda_{\mathrm{MgO}}$, and $\kappa_{\mathrm{CaO}}=\kappa_{\mathrm{MgO}}$ and $\kappa_{\mathrm{FeO}}=\kappa_{\mathrm{Fe} 2 \mathrm{O} 3}$. In such a way, we lowered to 24 the number of parameters to be calibrated (Table 4). Reference 
temperature and pressure were fixed to $1300^{\circ} \mathrm{C}$ and $0.1 \mathrm{MPa}$ respectively, such a choice having no effect on the quality of the fit. With the above boundary conditions, the model is able to reproduce the whole dataset $(\mathrm{Ar}+\mathrm{Ne}+\mathrm{He})$ within a standard error of $22 \%$ (Fig.8a). The standard errors for each single dataset (Ar, Ne, He) are similar (Fig. 8b, c, d).

We tested our model in two different ways: i) using an independent solubility database, and ii) comparing its performances to those of the existing models.

i) Ar solubility data can be extracted from diffusion studies, as the surface concentration in the quenched glasses correspond to the equilibrium solubility of the noble gas in the melt under experimental conditions (Behrens 2010a). We used the database given in Behrens (2010a) for peralkaline, metaluminous and peraluminous haplogranitic melts to compare measured Ar solubilities with the predictions of our model. Figure 9a shows how Ar solubilities measured at $\sim 800^{\circ} \mathrm{C}$ (the lower temperature limit of our model) and Ar contents calculated by our model at the relevant temperatures and pressures are in a good agreement. Moreover, we extrapolated model predictions to temperature lower than $800^{\circ} \mathrm{C}$ (down to $500^{\circ} \mathrm{C}$ ). Figure $9 \mathrm{~b}$ shows measured and calculated Ar solubilities in the metaluminous haplogranite as a function of temperature. The model accurately reproduces the inverse temperature dependence of Ar solubility at $200 \mathrm{MPa}$, but not the almost absence of temperature dependence at $400 \mathrm{MPa}$. However, glass transition, obviously not considered in our model, could affect model predictions below $800^{\circ} \mathrm{C}$. Calibration with solubility data obtained at lower temperatures would be therefore required.

ii) We used three different databases to compare the performances of our model, of the classical IP model (Carroll and Stolper 1993) and of the structural model of Marrocchi and Toplis (2005). The latter computes Ar solubility from the average polymerization state of the melt, without taking into account the temperature and the pressure at which the experiments were performed. The chosen experimental databases were: 1) synthetic compositions (Table 3) at constant temperature and pressure $\left(1600^{\circ} \mathrm{C}\right.$ and $\left.0.1 \mathrm{MPa}\right)$ (Marrocchi and Toplis, 2005); synthetic compositions (NS, NCS and CMS) at variable temperatures $\left(1200-1600^{\circ} \mathrm{C}\right)$ and relatively constant pressure (187-198 MPa) (Shibata et al., 1998); 2) natural compositions (basalt and rhyolite) at constant temperature $\left(1200^{\circ} \mathrm{C}\right)$ and variable pressures $(49-375 \mathrm{MPa})$ (this study). The structural model of Marrocchi and Toplis (2005) was calibrated using 1) and 2). Fig. 10 shows the predictions of the three models for these three datasets. The IP model 
generally overestimates Ar solubility, more strongly in synthetic compositions than in natural ones. Both our model and the one of Marrocchi and Toplis (2005) satisfactorily reproduce the isothermal dataset of Marrocchi and Toplis (2005), with similar confidence $\left(\mathrm{R}^{2}\right.$ of 0.96 and 0.95, respectively). However, our model yields more accurate results than the model of Marrocchi and Toplis (2005) for the datasets obtained at different temperatures (Shibata et al 1998) and pressures (this study). This underlines the need of a predictive model for noble gases solubility that takes into account temperature and pressure effects.

As concerns the pressure effect, Figure 11 shows experimental data between 0.1 and $\sim 2500$ MPa for rhyolitic, albitic and basaltic compositions. Our data, together with the ones of Carroll and Stolper (1993), allow bridging low to high pressure data. A clear linear relation between Ar pressure and dissolved concentration for both basaltic and rhyolitic compositions emerges, which is well reproduced by our model calculations (Fig. 11). In agreement with Guillot and Sarda (2006), who modeled noble gas solubility by using a Hard Sphere approach, this result suggests that the concurrent compressions of both liquid and gas phases balance their effects to some extent. At higher pressures, the calculated concentrations in the melt display a threshold behavior, because the decrease in solubility due to the decreasing IP is no more balanced by the increase in gas fugacity. The melt compaction most likely becomes dominant on gas compression (Guillot and Sarda, 2006). The experimental data of Schmidt and Keppler (2002) support this hypothesis, suggesting that this cross-over occurs at pressures of $\sim 5 \mathrm{GPa}$. Although not included in our calibration, these data for basaltic and granitic melts are well reproduced by our model up to 2-3 GPa (Fig.8b, 11), but depart significantly from it at higher pressures. Experimental data in silica and olivine melts show, however, drastic decreases in Ar solubility occurring over a relatively narrow pressure range (4-5.5 GPa), which have been interpreted to be linked to a major change in the structure of the silicate liquid (ChamorroPerez et al., 1996, 1998; Bouhifd et al., 2008), rather than to melt compaction. Accounting for this data is however beyond the aim of our model, which is calibrated mainly for simulating magmatic degassing from reservoirs located in the upper crust or in the oceanic lithosphere. Our model accounts for the direct relation between solubility and temperature of mafic liquids. A plot of $-\ln (k)$ vs. 1/T shows an almost linear relation, which, recalling that $-\ln \left(k_{\mathrm{g}}\right)=-$ $\Delta \mathrm{H} / \mathrm{R} \times\left(1 / \mathrm{T}-1 / \mathrm{T}^{\circ}\right)$, predicts a constant value of the solution enthalpy $\Delta \mathrm{H}$ (Fig.12). By fitting the model predictions with the above thermodynamic relation (see also Paonita, 2005), we 
estimate solution enthalpies for Ar ranging from $28 \mathrm{~kJ} / \mathrm{mol}$ for the MOR basalts, to $35 \mathrm{~kJ} / \mathrm{mol}$ for the alkali-olivine-basalts, very close to those estimated by Jambon et al. (1986) and Lux (1987). Interestingly, the model also predicts a slight inverse thermal dependence (Fig.12) of Ar solubility in albitic and rhyolitic compositions (solution enthalpies of -2.5 and $-9.8 \mathrm{~kJ} / \mathrm{mol}$, respectively), which has been observed at low-pressure in rhyolitic compositions (Carroll and Stolper, 1993). In accordance with the results of White et al. (1989), our model equally predicts that the solution enthalpies in silica-rich melts change their sign at high pressures, showing increasing Ar solubilities when temperature increases. By a similar thermodynamic approach, our model also predicts constant values of solution enthalpy for $\mathrm{He}$ and $\mathrm{Ne}$. In agreement with previous studies (Jambon et al., 1986; Lux, 1987; Carroll and Stolper, 1993), the enthalpies are positive for mafic liquids, and negative for acidic melts and silica.

\section{CONCLUDING REMARKS}

In this paper we present new experimental data of $\mathrm{Ar}$ and $\mathrm{Ne}$ solubility in basaltic and rhyolitic melts at moderate pressures. They include the first measurements of Ne solubility in natural melts at pressures higher than the atmospheric one. We propose a new predictive model that builds upon the idea of ionic porosity of silicate melt and accounts for the effects of melt composition, temperature and pressure on noble gas solubility. Our model has been calibrated using a large database of $\mathrm{He}, \mathrm{Ne}$ and $\mathrm{Ar}$ experimental solubilities in natural and synthetic silicate melts and is able to predict noble gas solubility up to $1600^{\circ} \mathrm{C}$ and $3 \mathrm{GPa}$ within $22 \%$ of uncertainty. A worksheet is provided (online supplementary data) to calculate Ar, Ne and He solubility starting from chemical composition of the melt, temperature and pressure.

Our work highlights that the concept of melt ionic porosity remains particularly useful to deal with noble gas solubility from a semi-theoretical point of view. However, further experimental studies are needed to fully calibrate the effect of pressure on $\mathrm{Ne}$ and $\mathrm{He}$ solubility and investigate the relationship between noble gas solubility and IP at very high pressures in natural melts. Moreover, to be useful in the context of magma degassing processes, the new IP model will also need to incorporate the effect of dissolved $\mathrm{H}_{2} \mathrm{O}$ and $\mathrm{CO}_{2}$ in melt on noble gas solubility. 
Acknowledgements. This work was funded by the INGV-DPC project V3-6 Etna (Task 2, RU 30). We are grateful to Giuseppe Riccobono for the mechanical support, to Jean-Michel Beny for the precious suggestions about the FTIR technique, to Mario Tantillo and Olivier Rouer for the technical assistance during QMS and EMP analyses respectively. We thank Harald Behrens for his constructive review and Donald Dingwell for the careful handling of the manuscript. Giada Iacono-Marziano acknowledges the European Community's Seventh Framework Programme (under grant agreement $\mathrm{n}^{\circ}$ PIEF-GA-2008-220926) that allowed this research to be accomplished.

\section{REFERENCES}

Behrens, H., 2010a. Noble gas diffusion in silicate glasses and melts. Rev. Mineral. Geochem. 72.

Bouhifd, M.A., Jephcoat, A.P., 2006. Aluminium control of argon solubility in silicate melts under pressure. Nature 439, 961-964.

Bouhifd, M.A., Jephcoat, A.P., Kelley S.P., 2008. Argon solubility drop in silicate melts at high pressures: A review of recent experiments. Chem. Geol. 256, 252-258.

Brawer, S. W, White, W. B., 1975. Raman spectroscopic investigation of the structure of silicate glasses, I. The binary silicates glasses. J. Chem. Phys. 63, 2421-2432.

Broadhurst, C. L., Drake, M. J., Hagee, B. E., Bernatowicz, T. J., 1992. Solubility and partitioning of $\mathrm{Ne}, \mathrm{Ar}, \mathrm{Kr}$ and $\mathrm{Xe}$ in minerals and synthetic basalts liquids. Geochim. Cosmochim. Acta 56, 709-723.

Caracausi, A., Italiano, F., Paonita, A., Rizzo, A., Nuccio, P.M., 2003. Evidence of deep magma degassing and ascent by geochemistry of peripheral gas emissions at Mount Etna (Italy): assessment of the magmatic reservoir pressure. J. Geophys. Res.108, 2463-2477.

Carroll, M. R., Stolper, E. M., 1991. Argon solubility and diffusion in silica glass: Implications for the solution behavior of molecular gases. Geochim. Cosmochim. Acta 211-225.

Carroll, M. R., Stolper, E. M., 1993. Noble gas solubilities in silicate and glasses: New experimental results for argon and the relationship between solubility and ionic porosity. Geochim. Cosmochim. Acta 57, 5039-5051.

Carroll, M. R., Webster, J. D., 1994. Experimental results applied to C-O-H in natural melts. In: Volatiles in Magmas. Reviews in Mineralogy 30, 231-279. 
Carroll, M. R., Sutton, S. R., Rivers, M. L., Woolum, D. S., 1993. An experimental study of krypton diffusion and solubility in silicic glasses. Chem. Geol. 109, 9-28.

Chamorro-Perez, E., Gillet, P., Jambon, A., 1996. Argon solubility in silicate melts at very high pressures. Experimental set-up and preliminary results for silica and anorthite melts. Earth Planet. Sci. Lett. 145, 97-107.

Chamorro-Perez, E., Gillet, P., Jambon, A., Badro, J., McMillan, P., 1998. Low argon solubility in silicates melts at high pressure. Nature 393, 352-355.

Chennaoui-Aoudjehane, H., Jambon, A., 1990. He solubility in silicates glasses at $250^{\circ} \mathrm{C}$ : A model for calculation. Eur. J. Mineral. 2, 539-545.

Di Carlo, I., Pichavant, M., Rotolo, S.G., Scaillet, B., 2006. Experimental crystallization of a high-K arc basalt: The golden pumice, Stromboli volcano (Italy). J. Petrol. 47, 1317-1343.

Doremus, R. H., 1966. Physical solubility of gases in fuse silica. J. Am. Ceram. Soc. 49, 461462.

Dowty, E., 1980. Crystal-chemical factors affecting the mobility of ions in minerals. Am. Mineral. 65, 174-182.

Fine, G., Stolper, E. M., 1986. Dissolved carbon-dioxide in basaltic glasses-concentration and speciation. Earth Planet. Sci. Lett. 76, 263-278.

Fortier, S. M., Giletti, B. J., 1989. An empirical model for predicting diffusion coefficients in silicate minerals. Science 245, 1481-1484.

Gaillard, F., Pichavant, M., Scaillet, B. 2003. Experimental determination of activities of FeO and $\mathrm{Fe}_{2} \mathrm{O}_{3}$ components in hydrous silicic melts under oxidizing conditions. Geochim Cosmochim Acta 67, 4389-4409.

Giordano, D., Romano, C., Papale, P., Dingwell, D.B., 2004. The viscosity of trachytes, and comparison with basalts, phonolites, and rhyolites. Chem. Geol. 213, 227-251.

Guillot, B., Sarda, P., 2006. The effect of compression on noble gas solubility in silicate melts and consequences for degassing at mid-ocean ridges. Geochim. Cosmochim. Acta 70, 12151230.

Hayatsu A., Waboso, C. E., 1985. The solubility of rare gases in silicates melts and implications for K-Ar dating. Chem. Geol. 52, 97-102. 
Heber, V.S., Brooker, R.H., Kelley, S.P., Wood, B.J., 2007. Crystal-melt partitioning of noble gases (helium, neon, argon, krypton, and xenon) for olivine and clinopyroxene, Geochim. Cosmochim. Acta 71, 1041-1061.

Jambon, A., Weber, H., Braun, O., 1986. Solubility of He, Ne, Ar, Kr and Xe in a basalt melt in the range $1250-1600^{\circ} \mathrm{C}$ : Geochemical implications. Geochim. Cosmochim. Acta 50, 401-408.

Jambon, A., 1986. He solubility in silicate melts: a tentative model of calculation. Chem. Geol. $62,131-136$.

Lange, R.A., Carmichael, I.S.E., 1987. Densities of $\mathrm{Na}_{2} \mathrm{O}-\mathrm{K}_{2} \mathrm{O}-\mathrm{MgO}-\mathrm{MgO}-\mathrm{FeO}-\mathrm{Fe}_{2} \mathrm{O}_{3}-\mathrm{Al}_{3} \mathrm{O}_{3}-$ $\mathrm{TiO}_{2}-\mathrm{SiO}_{2}$ liquids: New measurements and derived partial molar properties. Geochim. Cosmochim. Acta 51, 2931-2946.

Lesne, P., 2008. Etude expérimentale de la solubilité des volatils C-H-O-S dans les basaltes alcalins italiens. Simulations numériques du dégazage chimique : application à l'Etna. Unpublished PhD Thesis, Université d'Orléans.

Lux G., 1987. The behavior of noble gases in silicate liquids: Solution, diffusion, bubbles and surface effects, with applications to natural samples. Geochim. Cosmochim. Acta 51,15491560 .

Marrocchi, Y., Toplis, M. J., 2005. Experimental determination of argon solubility in silicate melts: An assessment of the effects of liquid composition and temperature. Geochim. Cosmochim. Acta 69, 5765-5776.

Mesko, M. G., Newton, K., Shelby, J.E., 2000. Helium solubility in sodium silicate glasses and melts, Phys. Chem. Glasses 41(3), 111-116.

Mesko, M. G., Shelby, J.E., 2002. Helium solubility in ternary soda-lime-silica glasses and melts, Phys. Chem. Glasses 43(2), 91-96.

Miyazaki, A., Hiyagon, H., Sugiura, N., Hirose, K., Takahashi, E., 2004. Solubilities of nitrogen and noble gases in silicates melts under various oxygen fugacities: Implications for the origin and the degassing history of nitrogen and noble gases in the Earth. Geochim. Cosmochim. Acta $68,387-401$.

Mulfinger, V. H. O., Dietzel, A., Navarro, J. M. F., 1972. Physical Solubility of Helium, Neon, and Nitrogen in Glass Melts, Glastech. Ber. 45, 389-96.

Newman, S., Stolper, E., Epstein S., 1986. Measurement of water in rhyolitic glasses: calibration of an infrared spectroscopic technique. Am. Mineral. 71, 1527-1541. 
Nuccio, P. M., Paonita, A., 2000. Investigation of the noble gas solubility in $\mathrm{H} 2 \mathrm{O}-\mathrm{CO} 2$ bearing silicates liquids at moderate pressure II. the extended ionic porosity (EIP) model. Earth Planet. Sci. Lett. 183, 499-512.

Paonita, A., Gigli, G., Gozzi, D., Nuccio, P. M., Trigila R., 2000. Investigation of the He solubility in $\mathrm{H}_{2} \mathrm{O}-\mathrm{CO}_{2}$ bearing silicate liquids at moderate pressure: a new experimental method. Earth Planet. Sci. Lett. 181, 595-604.

Paonita, A., 2005. Noble gas solubility in silicate melts: a review of experimentation and theory and implications regarding magma degassing processes. Annals Geophys. 48 (4/5), 647-669.

Papale, P., Moretti, R., Barbato, D., 2006. The compositional dependence of the saturation surface of $\mathrm{H} 2 \mathrm{O}+\mathrm{CO} 2$ fluids in silicate melts. Chem. Geol. 229, 78-95.

Roselieb, K., Rammensee, W., Büttner, H., Rosenhauer, M., 1992. Solubility and diffusion of noble gases in vitreous albite. Chem. Geol. 96, 241-266.

Roux J., Lefèvre A., 1992. A fast-quench device for internally heated pressure-vessels. Europ. J. Mineral. 4, 279-281.

Schmidt, B., Keppler, H., 2002. Experimental evidence for high noble gas solubilities in silicate melts under mantle pressures. Earth Planet. Sci. Lett. 195, 277-290.

Shackelford, J. F., Studt, P. L., Fulrath, R. M., 1972. Solubility of Gases in Glasses. II. He, Ne, and H2 in Fused Silica. J. Appl. Phys. 43, 1619-1626.

Shannon, R.D., Prewitt, C.T., 1969. Effective ionic radii in oxides and fluorides. Acta Cryst., 25, 925-946.

Shelby, J. E., 1976. Pressure dependence of helium and neon in vitreous silica. J. Appl. Phys. 47, 135-139.

Shibata, T., Takahashi, E., Matsuda, J., 1996. Noble gas solubility in binary CaO-SiO2 system. Geophys. Res. Lett. 23, 3139-3142.

Shibata, T., Takahashi, E., Matsuda, J., 1998. Solubility of neon, argon, krypton and xenon in binary and ternary silicates systems: A new view on noble gas solubility. Geochim. Cosmochim. Acta 62, 1241-1253.

Tournour, C.C., Shelby, J.E., 2008a. Helium solubility in alkali silicate glasses and melts, Phys. Chem. Glasses: Eur. J. Glass Sci. Technol., Part B, 49 207-15.

Tournour, C.C., Shelby, J.E., 2008b. Neon solubility in silicate glasses and melts, Phys. Chem. Glasses: Eur. J. Glass Sci. Technol., Part B, 49 2237-44. 
White, B. S., Brearley, M., Montana, A., 1989. Solubility of argon in silicates liquids at high pressure. Am. Mineral. 76, 8-26. 
Table 1. Starting material compositions (wt $\%)$

\begin{tabular}{lrrrr}
\hline & $\begin{array}{r}\text { Mt. Etna }^{a} \\
(\mathrm{n}=18)\end{array}$ & $\sigma^{b}$ & $\begin{array}{r}\text { Vulcano }^{c} \\
(\mathrm{n}=11)\end{array}$ & $\sigma^{d}$ \\
\hline $\mathrm{SiO}_{2}$ & 48.86 & 0.36 & 74.11 & 0.32 \\
$\mathrm{TiO}_{2}$ & 1.73 & 0.08 & 0.09 & 0.05 \\
$\mathrm{Al}_{2} \mathrm{O}_{3}$ & 16.77 & 0.19 & 13.18 & 0.15 \\
$\mathrm{FeO}^{*}$ & 9.71 & 0.31 & 1.93 & 0.23 \\
$\mathrm{MnO}$ & 0.19 & 0.10 & 0.10 & 0.06 \\
$\mathrm{MgO}$ & 6.65 & 0.13 & 0.20 & 0.08 \\
$\mathrm{CaO}$ & 9.86 & 0.17 & 1.14 & 0.11 \\
$\mathrm{Na}$ & 3.62 & 0.14 & 4.26 & 0.10 \\
$\mathrm{~K}_{2} \mathrm{O}$ & 1.93 & 0.08 & 4.98 & 0.07 \\
$\mathrm{P}_{2} \mathrm{O}_{5}$ & 0.68 & 0.11 & - & - \\
\hline & & & & -
\end{tabular}

(a) Average composition by EMPA of the alkali-basaltic starting glass.

(b) Standard deviation of (a)

(c) Average composition by EMPA of the rhyolitic obsidian.

(d) Standard deviation of (c)

$\mathrm{n}=$ number of analyses

* Total $\mathrm{Fe}$ as $\mathrm{FeO}$ 
Table 2. Run conditions and results of the $\mathrm{Ar}$ and Ne saturation experiments

\begin{tabular}{|c|c|c|c|c|c|c|c|c|}
\hline Sample & $\begin{array}{r}\mathrm{P}_{\text {tot }} \\
(\mathrm{MPa})\end{array}$ & $\begin{array}{r}\text { time } \\
\text { (h) }\end{array}$ & $\begin{array}{r}\text { bubble } \\
\text { occurrence }\end{array}$ & $\begin{array}{r}\text { Ar melt }^{a} \\
(\mathrm{ppm})\end{array}$ & $\begin{array}{r}\sigma^{b} \\
(\%)\end{array}$ & $\begin{array}{r}\mathrm{H}_{2} \mathrm{O} \text { melt }^{\mathrm{c}} \\
(\mathrm{wt} \%)\end{array}$ & $\begin{array}{l}\mathrm{P}_{\mathrm{H} 20}{ }^{d} \\
\text { (MPa) }\end{array}$ & $\begin{array}{r}\mathrm{k}_{\mathrm{Ar}}{ }^{e} \\
(\mathrm{MPa})\end{array}$ \\
\hline \multicolumn{9}{|l|}{ Basalt } \\
\hline BA061107 & 48.5 & 70 & no & $38(2)$ & 4 & $0.29(0.01)$ & 2.8 & $7.6 * 10^{5}$ \\
\hline BA181005 & 88.1 & 47 & no & $56(9)$ & 4 & $0.56(0.02)$ & 7.4 & $9.0^{*} 10^{5}$ \\
\hline BA301007 & 153 & 56 & no & $126(5)$ & 5 & $0.72(0.03)$ & 10.7 & $6.8^{*} 10^{5}$ \\
\hline BA011206 & 185.5 & 68 & no & 142 (19) & 3 & $0.60(0.02)$ & 8.1 & $7.4 * 10^{5}$ \\
\hline BA091107 & 275 & 71 & no & $200(13)$ & 3 & $0.51(0.05)$ & 6.2 & $7.9^{*} 10^{5}$ \\
\hline BA270206 & 308 & 76 & no & $252(35)$ & 6 & $0.40(0.03)$ & 4.2 & $7.1 * 10^{5}$ \\
\hline \multicolumn{9}{|l|}{ Rhyolite } \\
\hline RA060306 & 104 & 67 & many & $476(32)$ & 2 & $0.07(0.01)$ & 0.2 & $1.3 * 10^{5}$ \\
\hline RA011206 & 185.4 & 68 & few & 698 (89) & 3 & $0.11(0.02)$ & 0.4 & $1.7^{*} 10^{5}$ \\
\hline RA180206 & 349.5 & 65 & many & $1642(222)$ & 5 & $0.19(0.01)$ & 0.8 & $1.3^{*} 10^{5}$ \\
\hline RA190405 & 359.8 & 62 & many & $1525(147)$ & 3 & $0.31(0.02)$ & 1.7 & $1.4^{*} 10^{5}$ \\
\hline Sample & $\begin{array}{r}P_{\text {tot }} \\
(\mathrm{MPa})\end{array}$ & $\begin{array}{r}\text { time } \\
\text { (h) }\end{array}$ & $\begin{array}{r}\text { bubble } \\
\text { occurrence }\end{array}$ & $\begin{array}{r}\mathrm{Ne} \mathrm{melt}^{a} \\
(\mathrm{ppm})\end{array}$ & & $\begin{array}{r}\mathrm{H}_{2} \mathrm{O} \text { melt }{ }^{c} \\
(\mathrm{wt} \%)\end{array}$ & $\begin{array}{l}\mathrm{P}_{\mathrm{H} 2 \mathrm{O}}{ }^{d} \\
\text { (MPa) }\end{array}$ & $\begin{array}{r}\mathrm{k}_{\mathrm{Ne}} e^{e} \\
(\mathrm{MPa})\end{array}$ \\
\hline \multicolumn{9}{|l|}{ Basalt } \\
\hline$\overline{\mathrm{BN} 280706}$ & 67.8 & 68 & no & $140(14)$ & n.d. & $0.39(0.01)$ & 4.4 & $1.3^{*} 10^{5}$ \\
\hline BN010906 & 115 & 67 & no & 144 (13) & n.d. & $0.20(0.02)$ & 1.6 & $2.3^{*} 10^{5}$ \\
\hline BN220906 & 183 & 67 & no & $264(34)$ & n.d. & $0.22(0.02)$ & 1.8 & $2.1 * 10^{5}$ \\
\hline BN050208 & 260 & 67 & no & $412(32)$ & n.d. & $0.10(0.01)$ & 0.6 & $1.9 * 10^{5}$ \\
\hline BN070705 & 295.8 & 72 & no & $426(55)$ & n.d. & $0.37(0.01)$ & 3.7 & $2.1^{*} 10^{5}$ \\
\hline \multicolumn{9}{|l|}{ Rhyolite } \\
\hline$\overline{\mathrm{RN} 280706}$ & 100.2 & 68 & many & $748(63)$ & n.d. & $0.10(0.01)$ & 0.3 & $4.2 * 10^{4}$ \\
\hline RN010906 & 115.5 & 67 & no & $964(35)$ & n.d. & $0.06(0.01)$ & 0.1 & $3.7^{*} 10^{4}$ \\
\hline RN220906 & 183.4 & 67 & no & $1513(77)$ & n.d. & $0.11(0.01)$ & 0.4 & $3.8^{*} 10^{4}$ \\
\hline RN070705 & 298.7 & 72 & many & $2583(143)$ & n.d. & $0.15(0.01)$ & 0.6 & $3.6 * 10^{4}$ \\
\hline
\end{tabular}

All experiments were equilibrated at $1200^{\circ} \mathrm{C}$.

(a) Ar and Ne contents in the melt by QMS, standard deviations in brackets.

(b) Standard deviation of EMP analyses.

(c) $\mathrm{H}_{2} \mathrm{O}$ contents in the melt by FTIR, standard deviations in brackets.

(d) $\mathrm{H}_{2} \mathrm{O}$ pressures in the fluid phase calculated from (c), see text for explanation.

(e) Henry's constants calculated on a simple oxide basis, see text for explanation.

n.d.: not determined 
Table 3. Considered experimental database

\begin{tabular}{|c|c|c|c|c|}
\hline References & Noble gas & Melt composition & $\begin{array}{l}\text { Temperature } \\
\left({ }^{\circ} \mathrm{C}\right)\end{array}$ & $\begin{array}{l}\text { Pressure }^{b} \\
\text { (MPa) }\end{array}$ \\
\hline Shackelford et al. 1972 & $\mathrm{Ne}, \mathrm{He}$ & $\mathrm{SiO}_{2}$ & $900-1000$ & 0.1 \\
\hline Mulfinger et al. 1972 & $\mathrm{He}$ & $\mathrm{KS}, \mathrm{NS}$ & $1400-1480$ & 0.1 \\
\hline \multirow[t]{3}{*}{ Hayatsu and Waboso 1985} & $\mathrm{Ar}, \mathrm{Ne}$ & andesite & $1030-1300$ & 0.1 \\
\hline & & tholeiitic basalt & $1200-1400$ & \\
\hline & & alk. ol-basalt & 1200 & \\
\hline Jambon et al. 1986 & $\mathrm{Ar}, \mathrm{Ne}, \mathrm{He}$ & basalt & $1250-1600$ & 0.1 \\
\hline \multirow[t]{5}{*}{ Lux 1987} & $\mathrm{Ar}, \mathrm{Ne}, \mathrm{He}$ & andesite & $1275-1500$ & 0.1 \\
\hline & & leucititic basanite & & \\
\hline & & tholeiitic basalt & & \\
\hline & & ol-basalt & & \\
\hline & & ugandite & & \\
\hline \multirow[t]{7}{*}{ White et al. 1989} & $\mathrm{Ar}$ & basalt & $1400-1600$ & $900-2500$ \\
\hline & & granite & $1400-1600$ & \\
\hline & & $\mathrm{Ab}$ & $1350-1600$ & \\
\hline & & orthoclase & $1400-1600$ & \\
\hline & & $A b-A n$ & 1600 & \\
\hline & & Di & $1600-1750$ & \\
\hline & & $\mathrm{K}_{2} \mathrm{Si}_{4} \mathrm{O}_{9}$ & $1000-1600$ & \\
\hline Carroll and Stolper 1991 & $\mathrm{Ar}$ & $\mathrm{SiO}_{2}$ & $800-900$ & $20-140$ \\
\hline Roselieb et al. 1992 & $\mathrm{Ar}, \mathrm{Ne}$ & $\mathrm{Ab}$ & 750,1000 & $10-250$ \\
\hline Broadhurst et al. 1992 & $\mathrm{Ar}, \mathrm{Ne}$ & CAMS & 1300 & 0.1 \\
\hline \multirow[t]{6}{*}{ Carroll and Stolper 1993} & $\mathrm{Ar}$ & rhyolite & $800-900$ & $47-370$ \\
\hline & & $\mathrm{Ab}$ & $800-900$ & $160-210$ \\
\hline & & orthoclase & $800-900$ & $128-242$ \\
\hline & & basaltic andesite & 1200 & $64-215$ \\
\hline & & ridge basalt & 1200 & $25-150$ \\
\hline & & ol-tholeiite & $1225-1300$ & $250-1000$ \\
\hline \multirow[t]{2}{*}{ Chamorro-Perez at al. $1996^{a}$} & $\mathrm{Ar}$ & An & $1800-2000$ & $5000-10000$ \\
\hline & & $\mathrm{SiO}_{2}$ & $1350-1600$ & $2500-6000$ \\
\hline
\end{tabular}




\begin{tabular}{|c|c|c|c|c|}
\hline Chamorro-Perez et al. $1998^{a}$ & $\mathrm{Ar}$ & olivine & $2000-2150$ & $2000-6000$ \\
\hline \multirow[t]{4}{*}{ Shibata et al. 1998} & $\mathrm{Ar}, \mathrm{Ne}, \mathrm{He}$ & NS & $1200-1400$ & $187-196$ \\
\hline & & MS & 1600 & 108 \\
\hline & & NCS & $1200-1400$ & $187-196$ \\
\hline & & CMS & $1500-1600$ & 194-198 \\
\hline \multirow[t]{2}{*}{ Paonita et al. 2000} & $\mathrm{He}$ & rhyolite & 1090 & 119 \\
\hline & & trachybasalt & 1180 & \\
\hline Mesko et al. 2000 & $\mathrm{He}$ & NS & $1100-1500$ & 0.1 \\
\hline \multirow[t]{2}{*}{ Schmidt and Kepler $2001^{a}$} & $\mathrm{Ar}$ & haplogranite & $1500-1950$ & $1000-8200$ \\
\hline & & tholeiitic basalt & $1500-2000$ & $1000-9700$ \\
\hline Mesko and Shelby 2002 & $\mathrm{He}$ & $\mathrm{NCS}, \mathrm{SiO}_{2}$ & 1400 & 0.1 \\
\hline Marrocchi and Toplis 2005 & $\mathrm{Ar}$ & $\begin{array}{l}\text { An, Di, Ab, Ne, An- } \\
\text { Di, Di-Ab, Ab-Ne, } \\
\text { Ne-An, Ne-Di, An-Ab, } \\
\text { NAS, MAS, CAS }\end{array}$ & 1600 & 0.1 \\
\hline \multirow[t]{3}{*}{ Miyzaki et al. 2004} & $\mathrm{Ar}, \mathrm{Ne}$ & basalt & 1300,1500 & $0.1,187-202$ \\
\hline & & andesite & & \\
\hline & & Di-An & & \\
\hline \multirow[t]{2}{*}{ Heber et al. 2007} & $\mathrm{Ne}$ & $\mathrm{Di}-\mathrm{Ab}$ & 1200 & 112 \\
\hline & & $\mathrm{N}_{2} \mathrm{SFo}$ & 1005 & 101 \\
\hline Tournour and Shelby 2008(1) & $\mathrm{He}$ & NS, KS & $1100-1400$ & 0.1 \\
\hline Tournour and Shelby 2008(2) & $\mathrm{Ne}$ & NS & 1400 & 0.1 \\
\hline
\end{tabular}
(a) Not included in the model calibration
(b) Total pressure of the experiments

Ab: albite; An: anorthite; Di: diopside; Ne: nepheline.

N: Na; A: Al, S: $\mathrm{SiO}_{2}$; C: Ca; M: Mg; K: K. 
Table 4. Model parameters for Eq.10.

\begin{tabular}{|c|c|}
\hline \multicolumn{2}{|l|}{ Imposed } \\
\hline $\mathrm{T}^{\circ}\left({ }^{\circ} \mathrm{C}\right)$ & 1300 \\
\hline $\mathrm{P}^{\circ}(\mathrm{MPa})$ & 0.1 \\
\hline$v_{\mathrm{ca}, \mathrm{SiO} 2}{ }^{\circ}$ & 13.30 \\
\hline$v_{\mathrm{ca}, \mathrm{TiO}^{\circ}}{ }^{\circ}$ & 13.81 \\
\hline$v_{\mathrm{ca}, \mathrm{Al} 2 \mathrm{O} 3^{\circ}}$ & 20.18 \\
\hline$v_{\mathrm{ca}, \mathrm{FeO}}{ }^{\circ}$ & 7.05 \\
\hline$v_{\mathrm{ca}, \mathrm{Fe} 2 \mathrm{O} 3^{\circ}}$ & 20.47 \\
\hline$v_{\mathrm{ca}, \mathrm{MgO}}{ }^{\circ}$ & 7.57 \\
\hline$v_{\mathrm{ca}, \mathrm{CaO}}{ }^{\circ}$ & 9.15 \\
\hline$v_{\mathrm{ca}, \mathrm{Na} 2 \mathrm{O}^{\circ}}$ & 14.50 \\
\hline 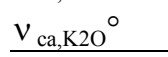 & 23.99 \\
\hline \multicolumn{2}{|l|}{ Calibrated } \\
\hline$v_{\mathrm{s}, \mathrm{SiO} 2}{ }^{\circ}$ & -7.18 \\
\hline$v_{\mathrm{s}, \mathrm{TiO} 2}{ }^{\circ}$ & -15.53 \\
\hline$v_{\mathrm{s}, \mathrm{Al} 2 \mathrm{O} 3^{\circ}}$ & -10.12 \\
\hline$v_{\mathrm{s}, \mathrm{FeO}}{ }^{\circ}$ & -1.97 \\
\hline$v_{\mathrm{s}, \mathrm{Fe} 2 \mathrm{O} 3^{\circ}}$ & -9.03 \\
\hline$v_{\mathrm{s}, \mathrm{MgO}}{ }^{\circ}$ & -2.20 \\
\hline$v_{\mathrm{s}, \mathrm{CaO}}{ }^{\circ}$ & -2.10 \\
\hline$v_{\mathrm{s}, \mathrm{Na} 2 \mathrm{O}^{\circ}}$ & -8.31 \\
\hline$v_{\mathrm{s}, \mathrm{K} 2 \mathrm{O}^{\circ}}$ & -13.37 \\
\hline$v_{q, N a 2 O^{\circ}}$ & 6.37 \\
\hline$\lambda_{\mathrm{SiO} 2}$ & -770.13 \\
\hline$\lambda_{\mathrm{TiO} 2}$ & 0 \\
\hline$\lambda_{\mathrm{Al} 2 \mathrm{O} 3}$ & -2811.1 \\
\hline$\lambda_{\mathrm{FeO}}$ & 0 \\
\hline$\lambda_{\mathrm{Fe} 2 \mathrm{O} 3}$ & -4139.6 \\
\hline$\lambda_{\mathrm{MgO}}, \lambda_{\mathrm{CaO}}$ & 2118.9 \\
\hline$\lambda_{\mathrm{Na} 2 \mathrm{O}}, \lambda_{\mathrm{K} 2 \mathrm{O}}$ & 6100.4 \\
\hline$\lambda_{\mathrm{q}, \mathrm{Na} 2 \mathrm{O}}$ & -7459.9 \\
\hline$\kappa_{\mathrm{SiO} 2}$ & $-2.1 \times 10^{-6}$ \\
\hline$\kappa_{\mathrm{TiO} 2}$ & 0 \\
\hline$\kappa_{\mathrm{Al} 2 \mathrm{O} 3}$ & $3.9 \times 10^{-5}$ \\
\hline$\kappa_{\mathrm{FeO},} \kappa_{\mathrm{Fe} 2 \mathrm{O} 3}$ & $1.0 \times 10^{-4}$ \\
\hline$\kappa_{\mathrm{MgO},} \kappa_{\mathrm{CaO}}$ & $4.7 \times 10^{-5}$ \\
\hline$\kappa_{\mathrm{Na} 2 \mathrm{O}}$ & $1.6 \times 10^{-4}$ \\
\hline$\kappa_{\mathrm{K} 2 \mathrm{O}}$ & $7.1 \times 10^{-5}$ \\
\hline$\kappa_{\mathrm{q}, \mathrm{Na} 2 \mathrm{O}}$ & 0 \\
\hline$\alpha_{\mathrm{Ar}}$ & 0.512 \\
\hline$\beta_{\mathrm{Ar}}$ & -53.10 \\
\hline$\alpha_{\mathrm{Ne}}$ & 0.401 \\
\hline$\beta_{\mathrm{Ne}}$ & -43.36 \\
\hline$\alpha_{\mathrm{He}}$ & 0.341 \\
\hline$\underline{\beta_{\mathrm{He}}}$ & -38.45 \\
\hline
\end{tabular}

Units are: $v_{\mathrm{ca}}$ and $v_{\mathrm{s}}\left[\mathrm{cm}^{3} \mathrm{~mol}^{-1}\right] ; \lambda\left[\mathrm{cm}^{3}{ }^{\circ} \mathrm{C} \mathrm{mol}^{-1}\right] ; \kappa\left[\mathrm{cm}^{3} \mathrm{~mol}^{-1} \mathrm{bar}^{-1}\right] . v_{\mathrm{ca}}$ calculated by summing cation and anion volumes in oxide, as in the classic IP model (ionic radii by Shannon and Prewitt, 1969). 


\section{Figure Captions}

Fig.1 EMP counts on the Ar peak versus Ar contents measured by QMS in the basaltic (a) and the rhyolitic (b) melt. The error bars illustrate the standard deviations of both EMP and QMS analyses. Ar-free glasses were also analyzed to check the background EMP counts.

Fig.2 Examples of $\mathrm{Ar}$ and $\mathrm{Ne}$ release curves (expressed as $\mathrm{Ar}$ and $\mathrm{Ne}$ pressures in mbar), measured by QMS as a function of temperature. Note that Ne degasses at lower temperatures than Ar, for both the basaltic (a) and the rhyolitic (b) melts.

Fig.3 Experimental solubilities of $\mathrm{Ar}(\mathrm{a})$ and $\mathrm{Ne}(\mathrm{b})$ in the basaltic and rhyolitic melts as a function of their partial pressure in the fluid phase. The error bars illustrate the standard deviation of the QMS analyses. The lines represent the best fit of the experimental data. Ne solubility data in albitic melts from Roselieb et al. (1992) are also shown in (b).

Fig.4 Ar solubility as a function of pressure in rhyolitic (a) and basaltic (b) melts (data from Carroll and Stolper, 1993 and this study). The experimental data for the basaltic composition are all at $1200^{\circ} \mathrm{C}$, except for the ridge basalt $\left(\mathrm{T}=1225^{\circ} \mathrm{C}\right.$; Carroll and Stolper, 1993). For the rhyolitic compositions, our experiments were performed at $1200^{\circ} \mathrm{C}$, while the experimental temperatures of Carroll and Stolper (1993) are between 800 and $900^{\circ} \mathrm{C}$. The lines represent the solubilities predicted by the IP model (Carroll and Stolper, 1993) for the different melt compositions at the relevant temperatures.

Fig.5 Ar solubility as a function of the melt ionic porosity for binary and ternary synthetic systems at $0.1 \mathrm{MPa}$ and $1600^{\circ} \mathrm{C}: \mathrm{Na}_{2} \mathrm{O}-\mathrm{SiO}_{2}$ (filled triangles), $\mathrm{CaO}-\mathrm{SiO}_{2}$ (filled circles), $\mathrm{MgO}-$ $\mathrm{SiO}_{2}$ (filled square), and $\mathrm{CaO}-\mathrm{MgO}-\mathrm{SiO}_{2}, \mathrm{Na}_{2} \mathrm{O}-\mathrm{CaO}-\mathrm{SiO}_{2}$ (asterisks); data from Shibata et al. (1998). The pure silica end-member has been characterized by Carroll and Stolper (1991). The arrows indicate the two components mixtures and the most probable position of the $\mathrm{Na}_{2} \mathrm{O}, \mathrm{CaO}$ and $\mathrm{MgO}$ end-members. Data from Marrocchi and Toplis (2005) in the CNMAS system are also shown (open squares).

Fig.6 Ar solubility as a function of the melt ionic porosity for natural and synthetic melt run at $0.1 \mathrm{MPa}$ and different temperatures. The label "Synthetic" stands for $\mathrm{CaO}-\mathrm{Na}_{2} \mathrm{O}-\mathrm{MgO}-\mathrm{Al}_{2} \mathrm{O}_{3}$ $\mathrm{SiO}_{2}$ melts (Table 3). Data from: Hayatsu and Waboso, 1985 (triangles, 1200-1400 ${ }^{\circ} \mathrm{C}$ ); Jambon et al., 1986 (diamonds, 1250-1600 ${ }^{\circ} \mathrm{C}$ ); Lux, 1987 (circles and crosses, 1200-1600 ${ }^{\circ} \mathrm{C}$ ); Marrocchi and Toplis, 2005 (squares, $1600^{\circ} \mathrm{C}$ ). The straight line highlights the trend of the experiments performed at $1600^{\circ} \mathrm{C}$. The experiments performed at lower temperatures are shifted towards lower Ar solubilities and lower ionic porosities.

Fig.7 Ar solubility as a function of the melt ionic porosity for natural and synthetic melts run at $1600^{\circ} \mathrm{C}$ and different pressures. The label "Synthetic" stands for $\mathrm{CaO}-\mathrm{Na}_{2} \mathrm{O}-\mathrm{MgO}-\mathrm{Al}_{2} \mathrm{O}_{3}-\mathrm{SiO}_{2}$ melts (Table 3). Data from: White et al., 1989 (triangles, dashes and open squares, 900-2500 $\mathrm{MPa}$ ); Schmidt and Keppler, 2001 (asterisks and diamonds, 1-3.8 GPa); Marrocchi and Toplis, 2005 (filled squares, $0.1 \mathrm{MPa}$ ). The straight line highlights the trend of the experiments performed at $0.1 \mathrm{MPa}$. The increasing pressure shifts the data towards lower ionic porosities and Ar solubilities.

Fig.8 Measured versus theoretical Ar, Ne and He solubilities calculated using our model. (a) Ar, $\mathrm{Ne}$ and He data together. (b) Ar experimental data from Hayatsu and Waboso, 1958; Jambon et al., 1986; Lux, 1987; White et al., 1989; Carroll and Stolper, 1991, 1993; Roselieb et al., 1992; 
Broadhurst et al., 1992; Shibata et al., 1998; Miyazaki et al., 2004; Marrocchi and Toplis, 2005; this study. Open diamonds represent the data used to calibrate the model, while the other symbols show the data of Schmidt and Keppler (2002) up to $3 \mathrm{GPa}$, which were not employed in the calibration (HPG: haplogranite, Tho: tholeiite). (c) Ne experimental data from Shackelford et al., 1972; Hayatzu and Waboso, 1985; Jambon et al., 1986; Lux, 1987; Roselieb et al., 1992; Broadhurst et al., 1992; Shibata et al., 1998; Miyzaki et al., 2004; Heber et al., 2007; Tournour and Shelby, 2008b; this study. (d) He experimental data from Shackelford et al., 1972; Mulfinger et al., 1972; Jambon et al., 1986; Lux, 1987; Shibata et al., 1998; Paonita et al., 2000; Mesko et al., 2000; Mesko and Shelby, 2002; Tournour and Shelby, 2008 a.

Fig.9 (a) Measured versus predicted Ar solubilities in peralkaline, metaluminous, and peraluminous haplogranitic melts at temperatures between 776 and $845^{\circ} \mathrm{C}$ and pressures between 50 and $400 \mathrm{MPa}$ (experimental data from Behrens 2010 and references therein). Horizontal error bars represent the model standard error of 24\%. (b) Measured and predicted Ar solubilities in the metaluminous haplogranite as a function of temperature at 200 and $400 \mathrm{MPa}$.

Fig.10 Measured versus calculated Ar solubilities using (a) the classical IP model of Carroll and Stolper (1993), (b) the structural model of Marrocchi and Toplis (2005) and (c) our model. Experimental data are from Shibata et al. (1998), Marrocchi and Toplis (2005) and this study.

Fig.11 Ar solubility as a function of pressure from 0.1 to $3000 \mathrm{MPa}$. Symbols represent experimental data at $1200^{\circ} \mathrm{C}$ (Carroll and Stolper 1993 and this study) and $1500^{\circ} \mathrm{C}$ (Jambon et al., 1986; White et al., 1989; Schmidt and Keppler, 2002). Lines represent model predictions at 1200 and $1500^{\circ} \mathrm{C}$ for rhyolitic and tholeiitic compositions.

Fig.12 Ar solubility as a function of temperature predicted by our model at $0.1 \mathrm{MPa}$ for different melt compositions. Note how Ar solubility increases with temperature in mafic melts, while it decreases in silicic melts.

Electronic Supplementary Material. Microsoft Excel file that contains a spreadsheet to calculate $\mathrm{Ar}, \mathrm{Ne}$ and $\mathrm{He}$ solubility (starting from melt composition, temperature and, only for Ar, pressure) using the model presented in this paper. 
a)

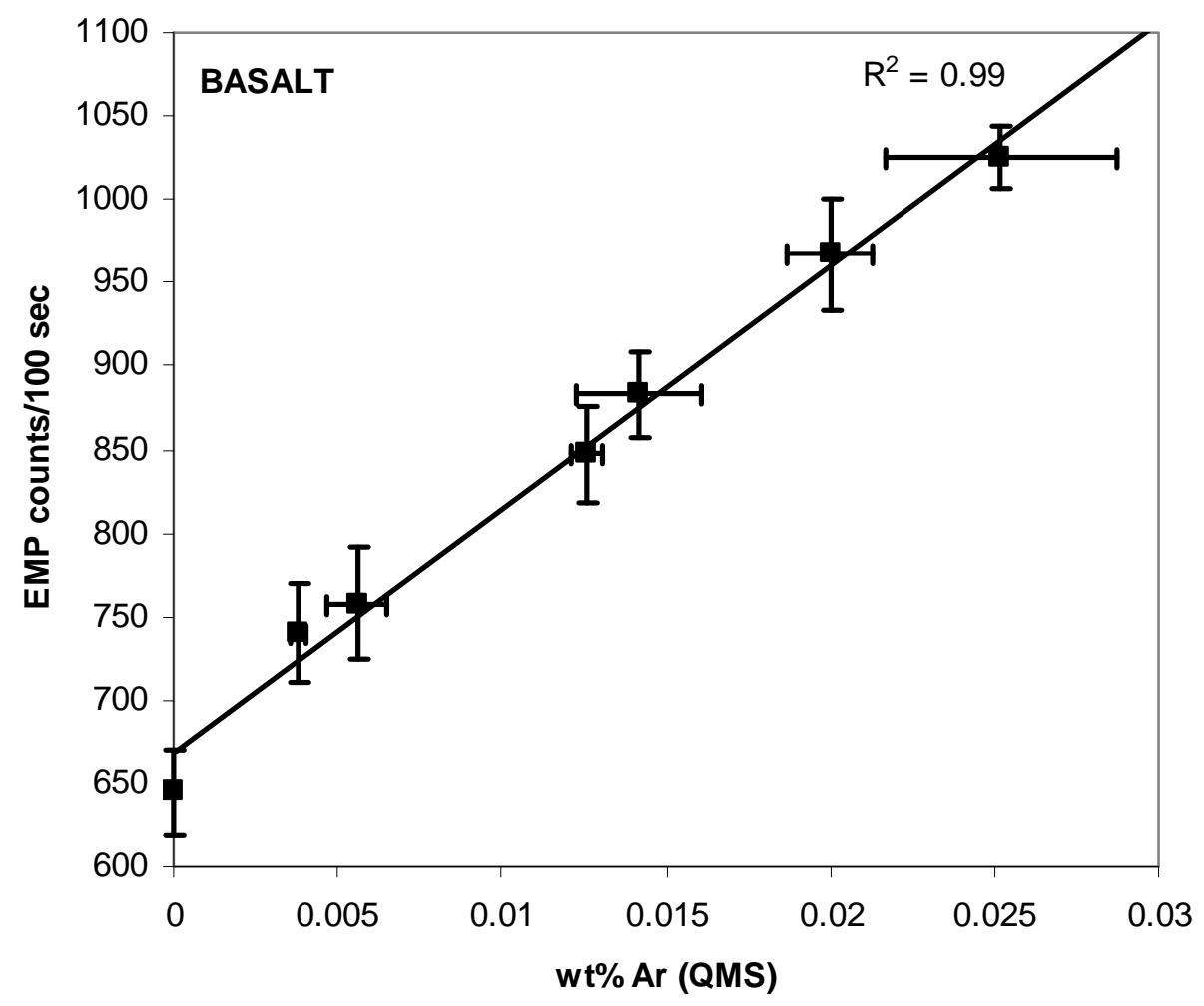

b)

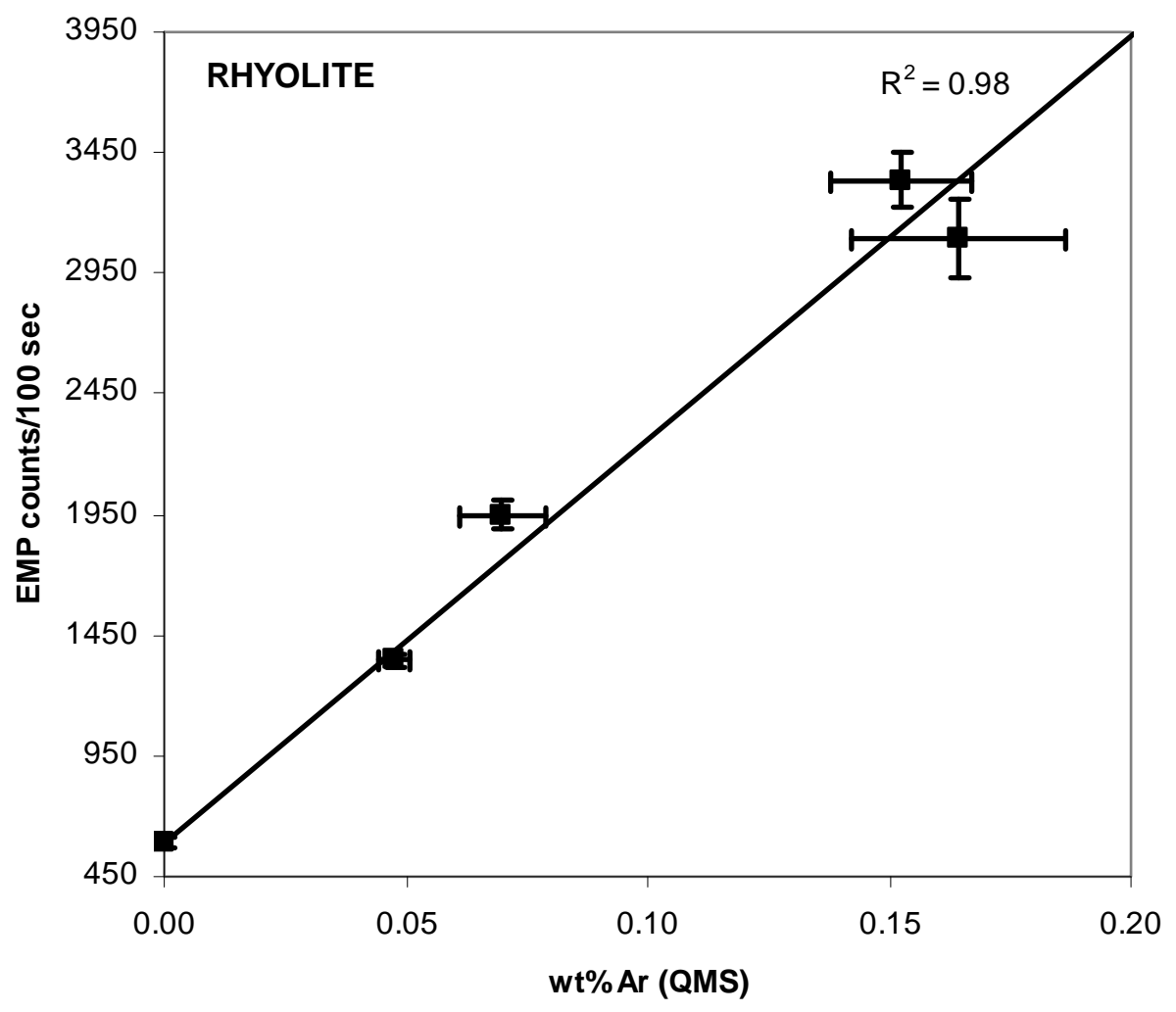

Fig.1 
a)

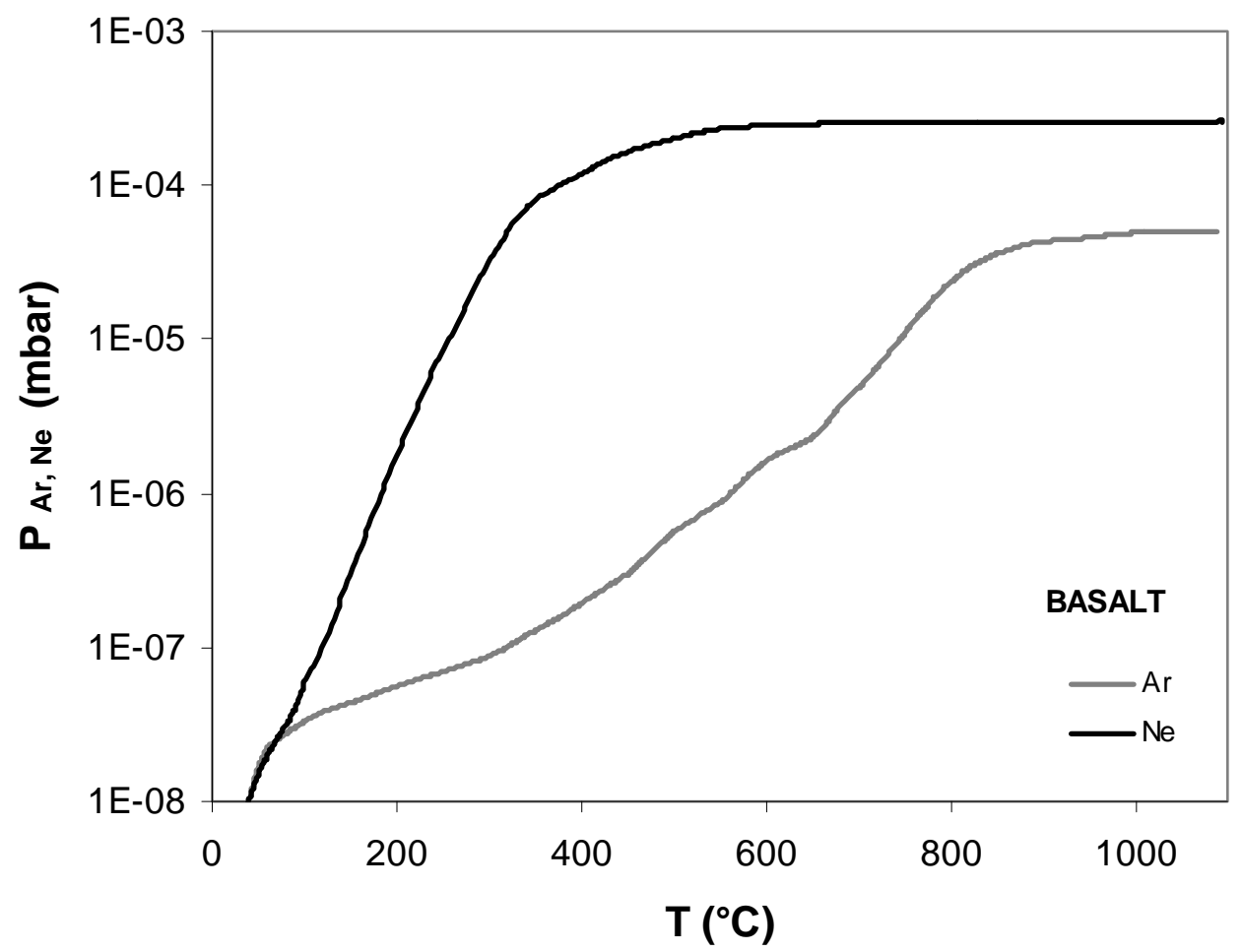

b)

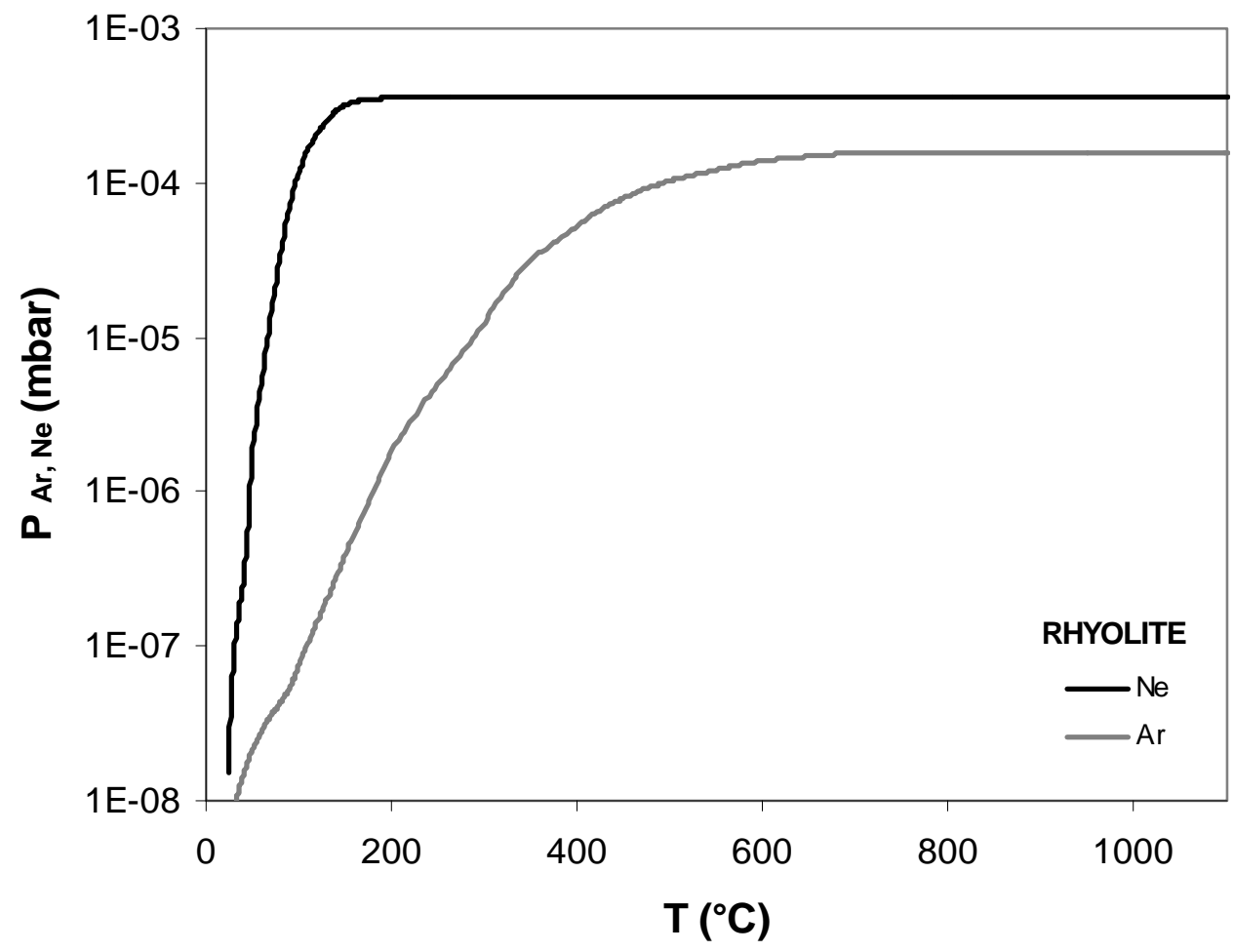

Fig.2 
a)
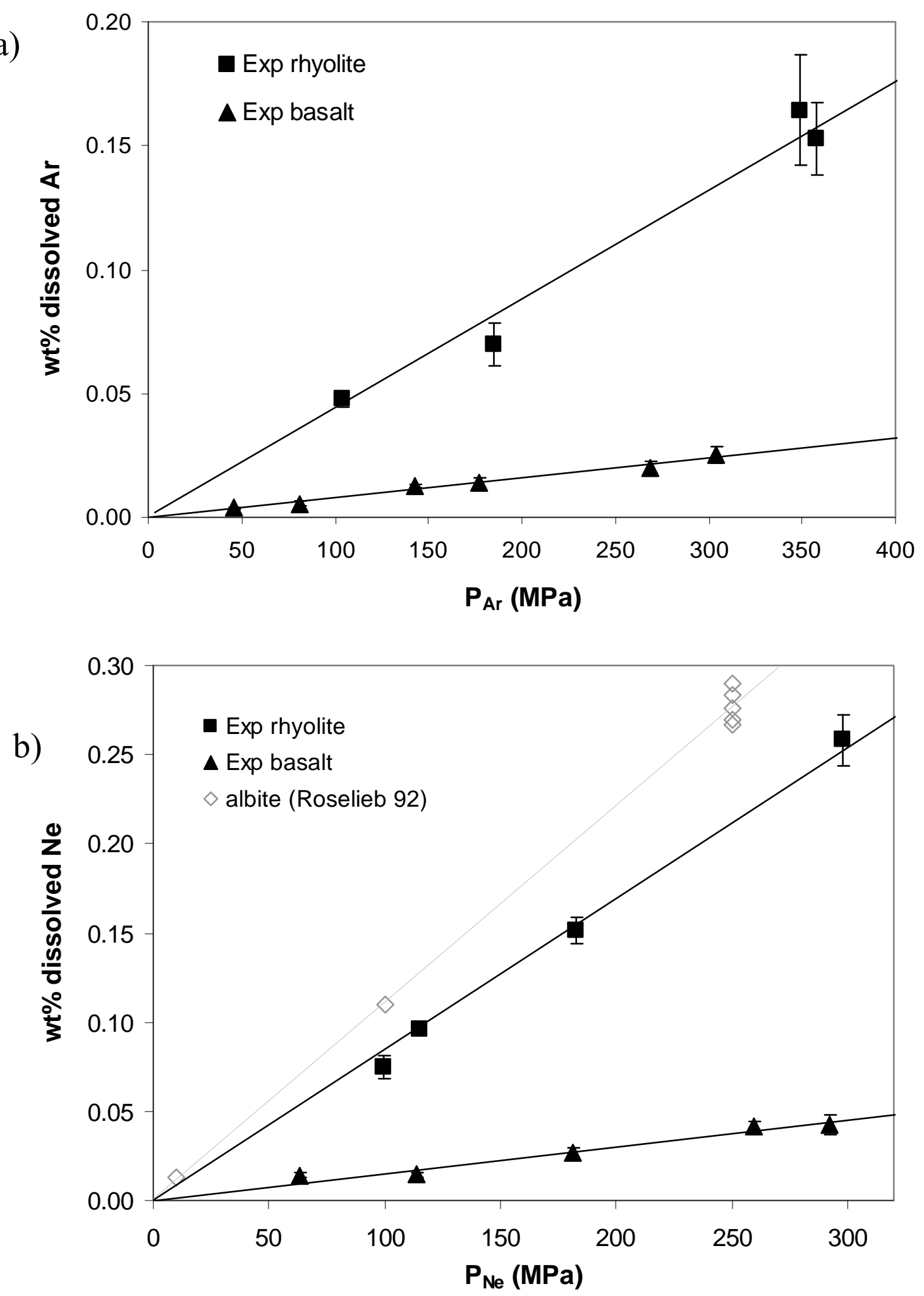

Fig.3 
a)

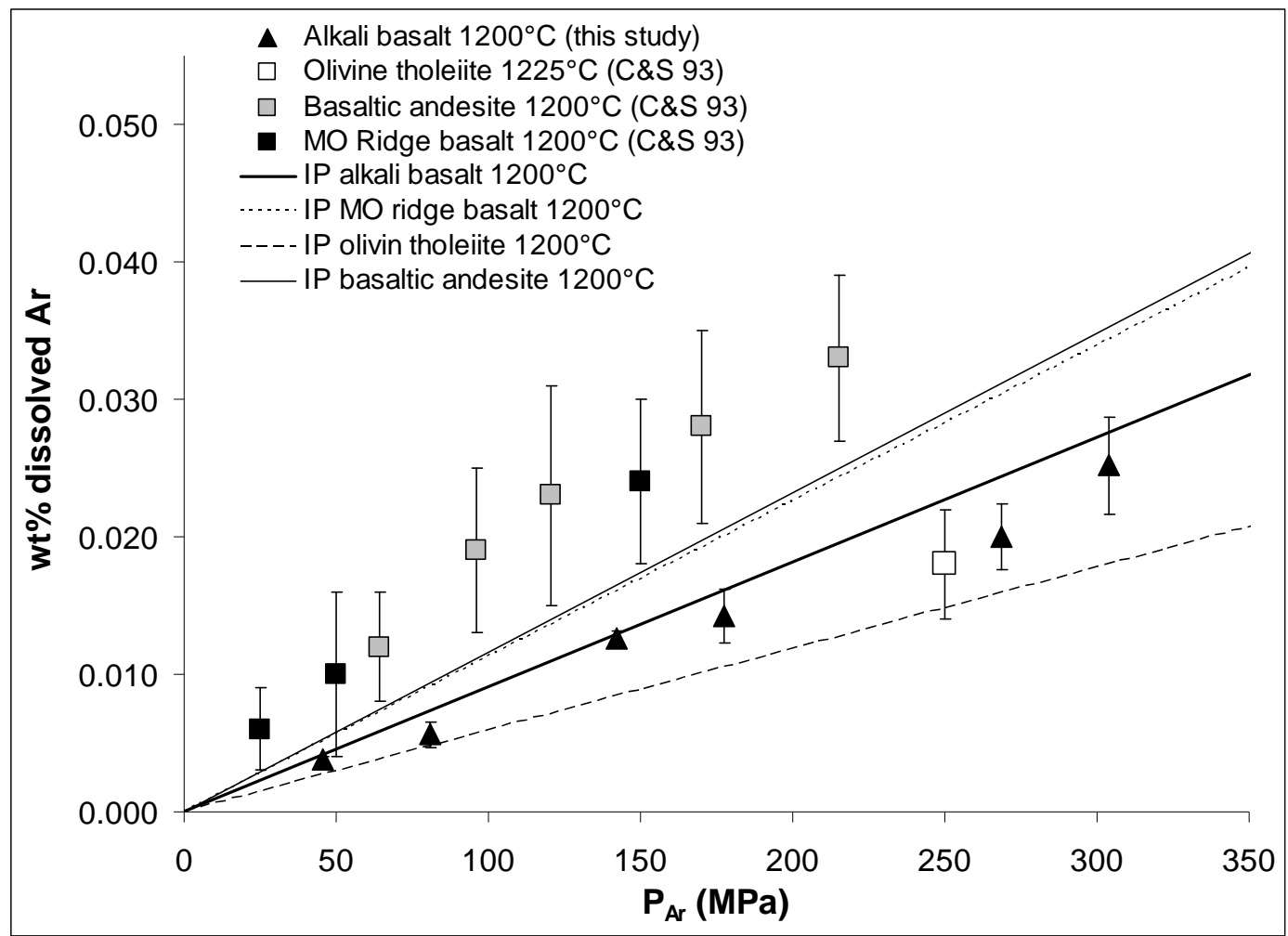

b)

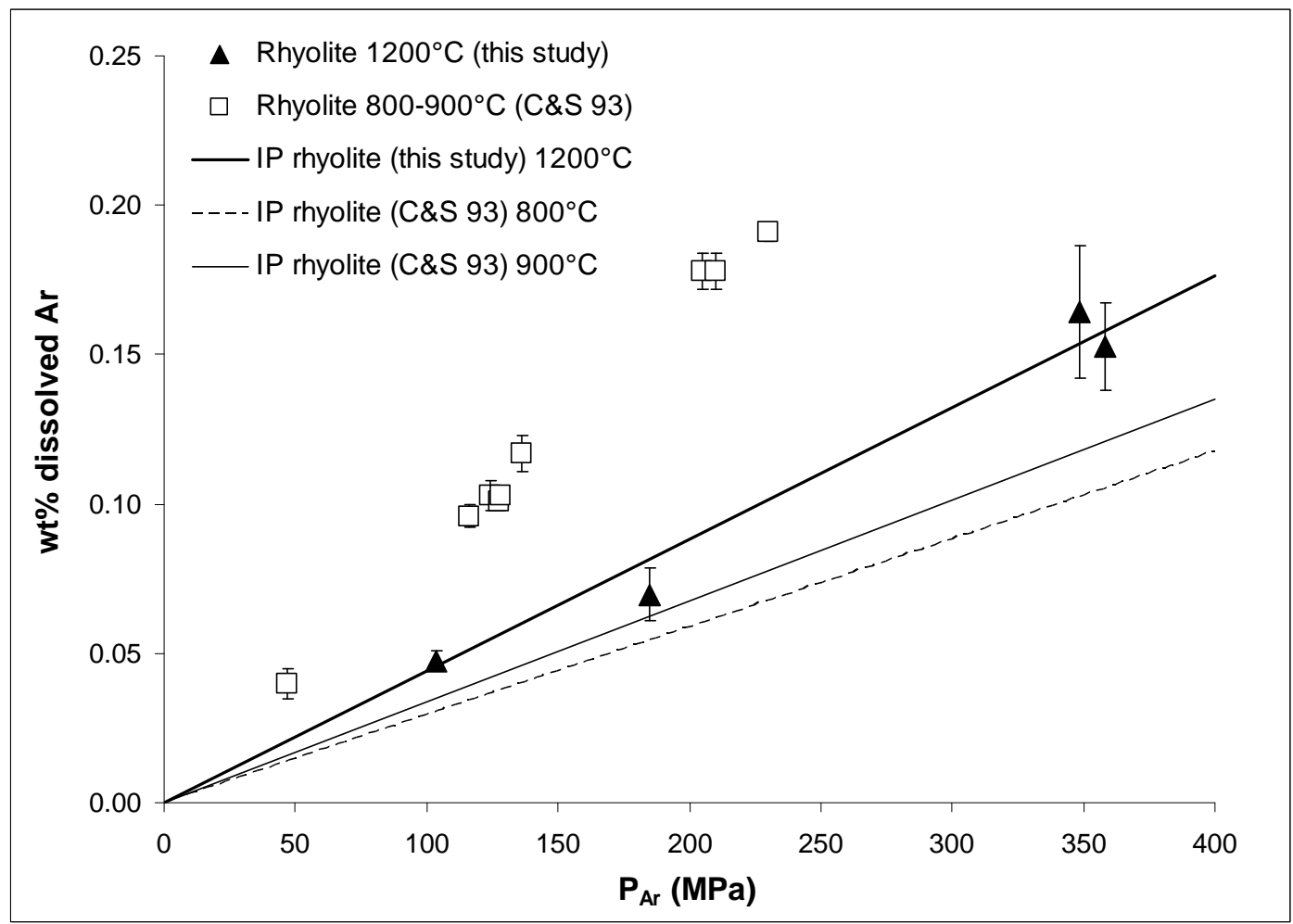

Fig. 4 


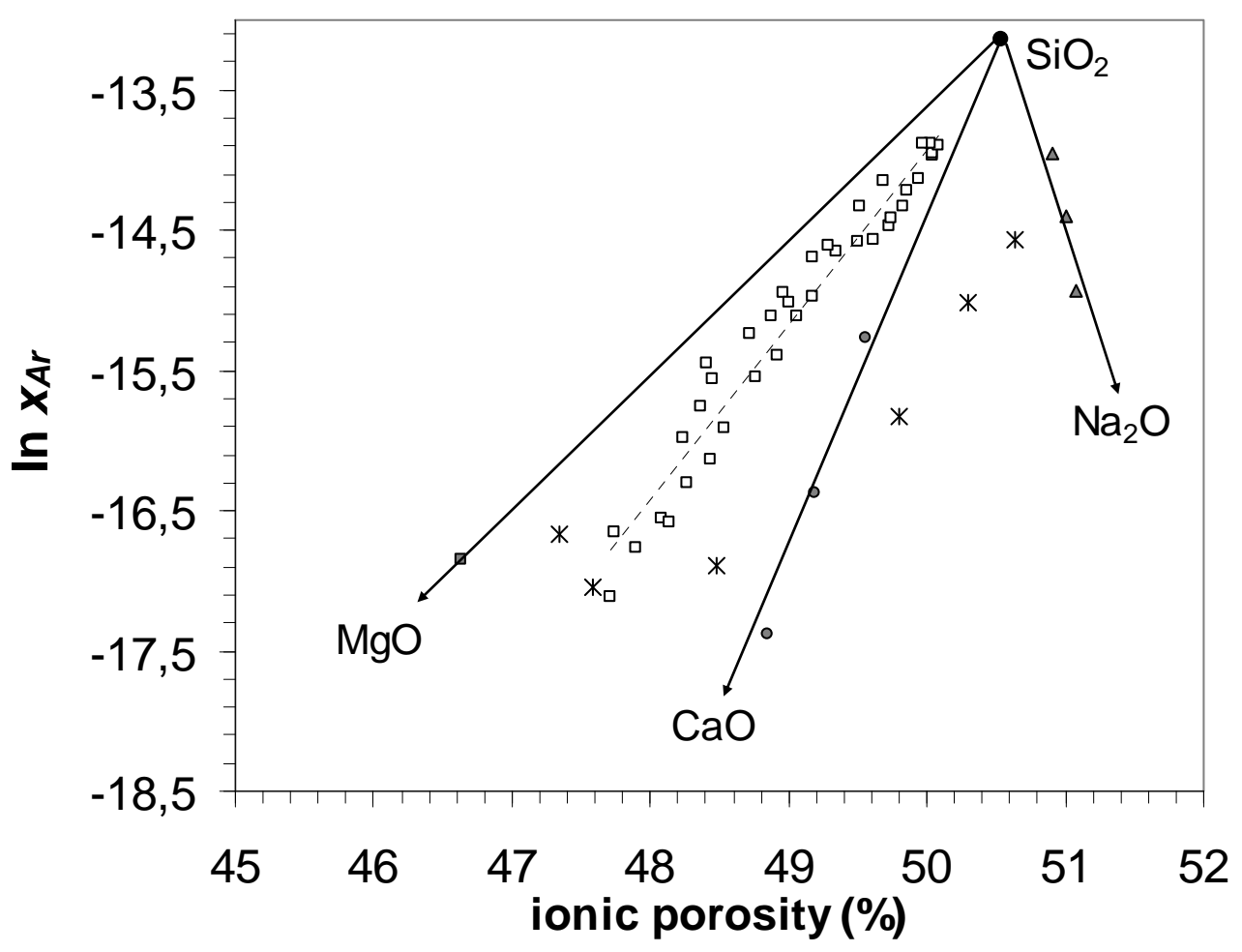

Fig. 5 


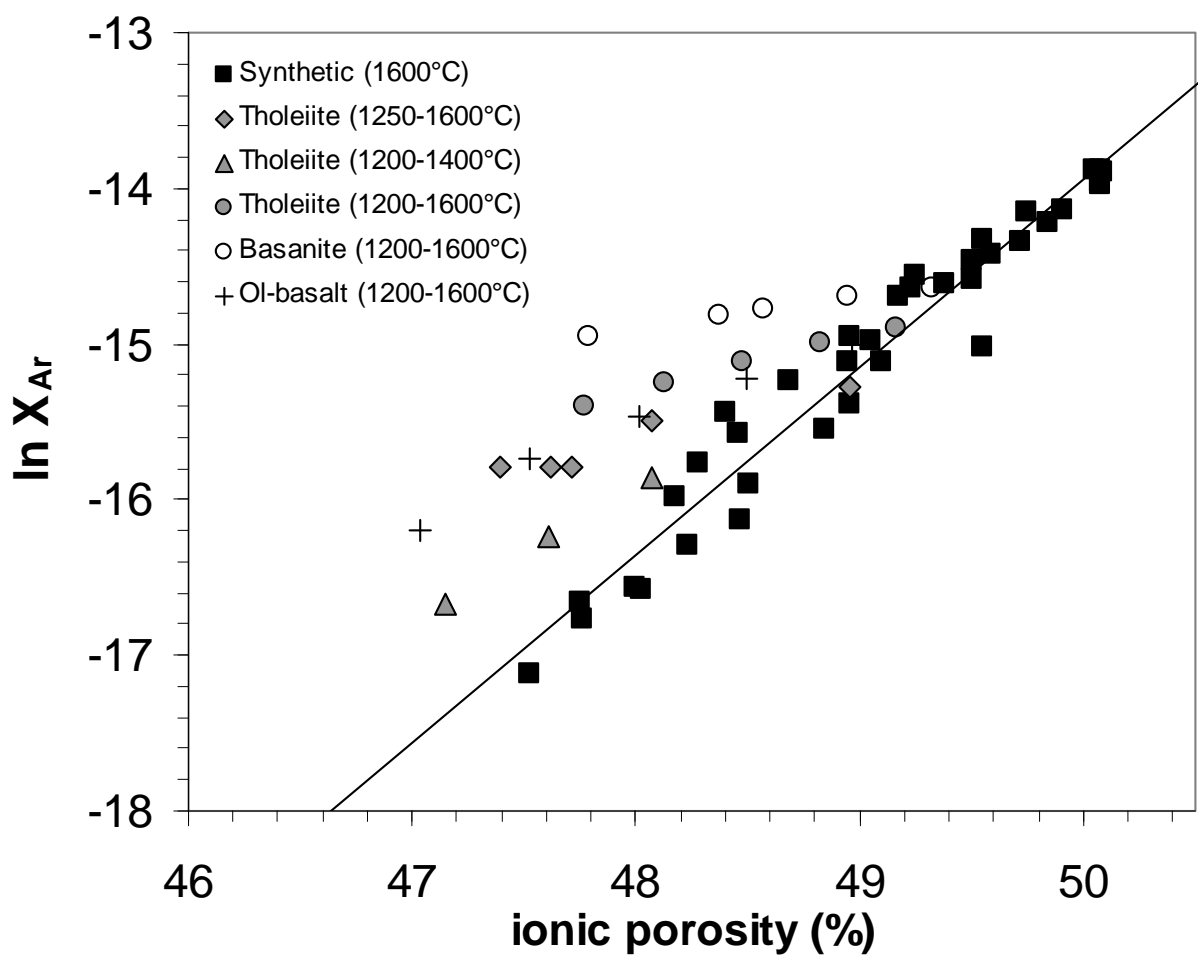

Fig. 6 


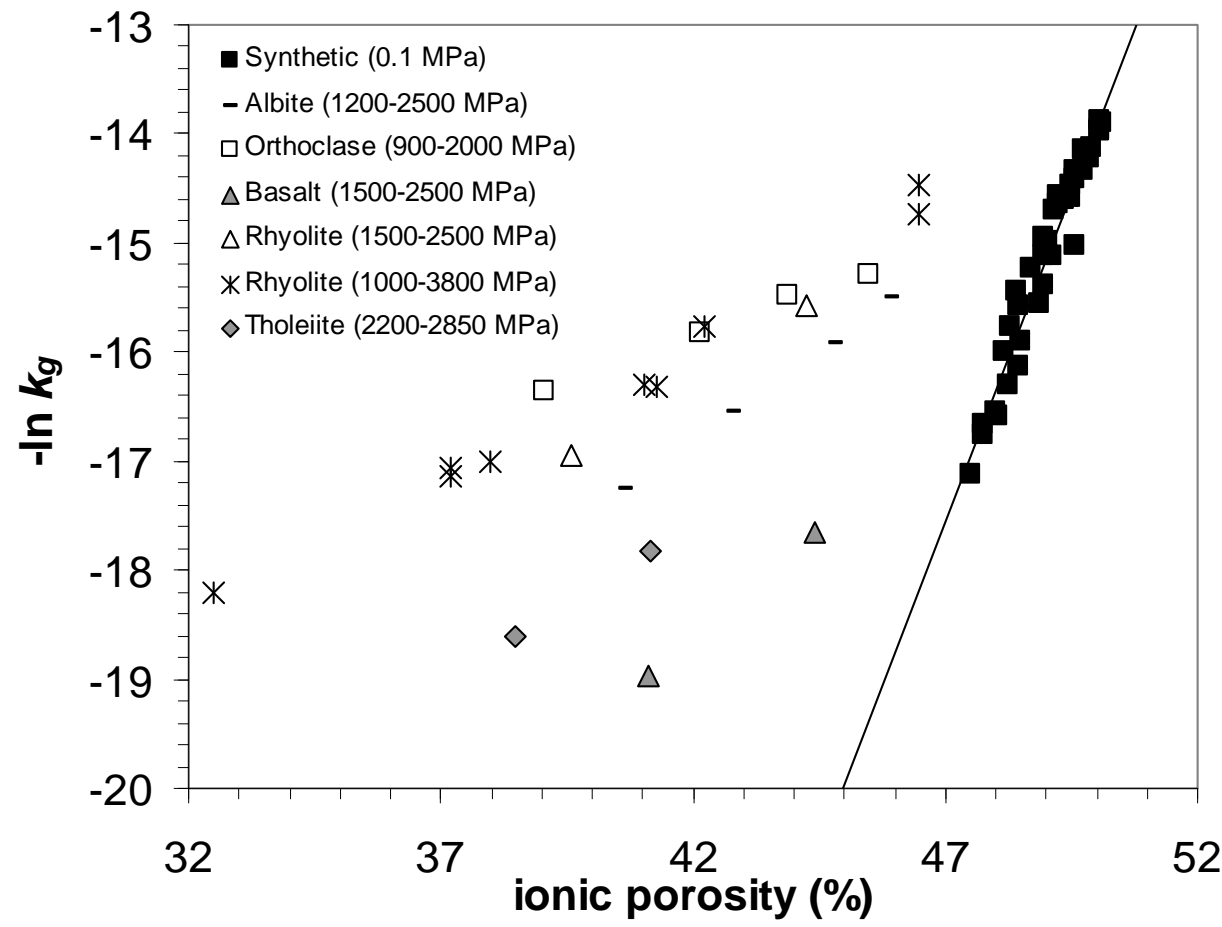

Fig. 7 

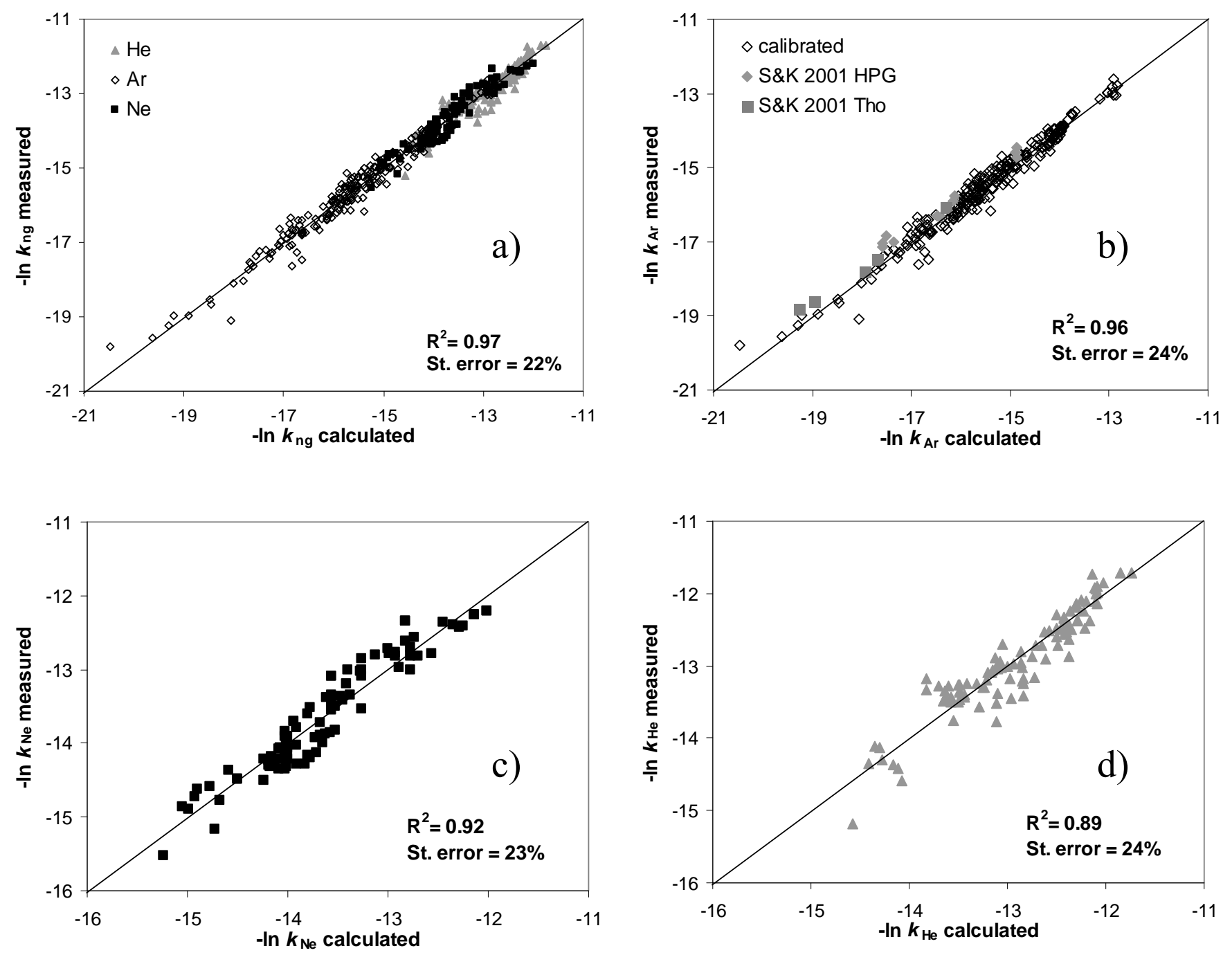

Fig. 8 
a)

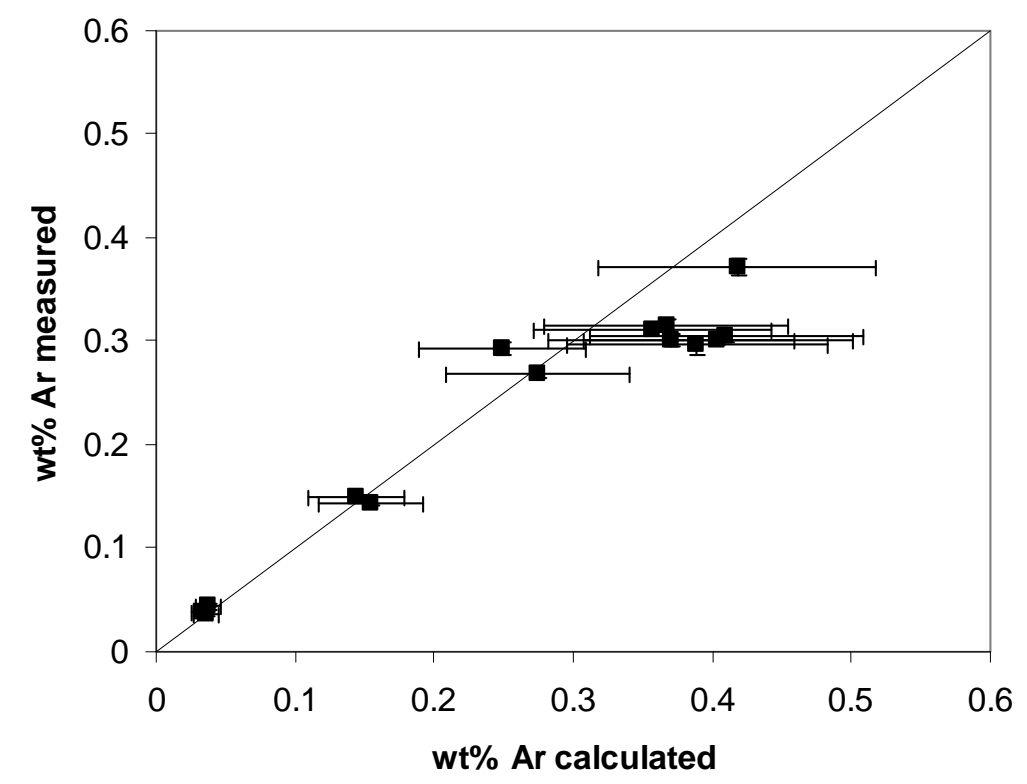

b)

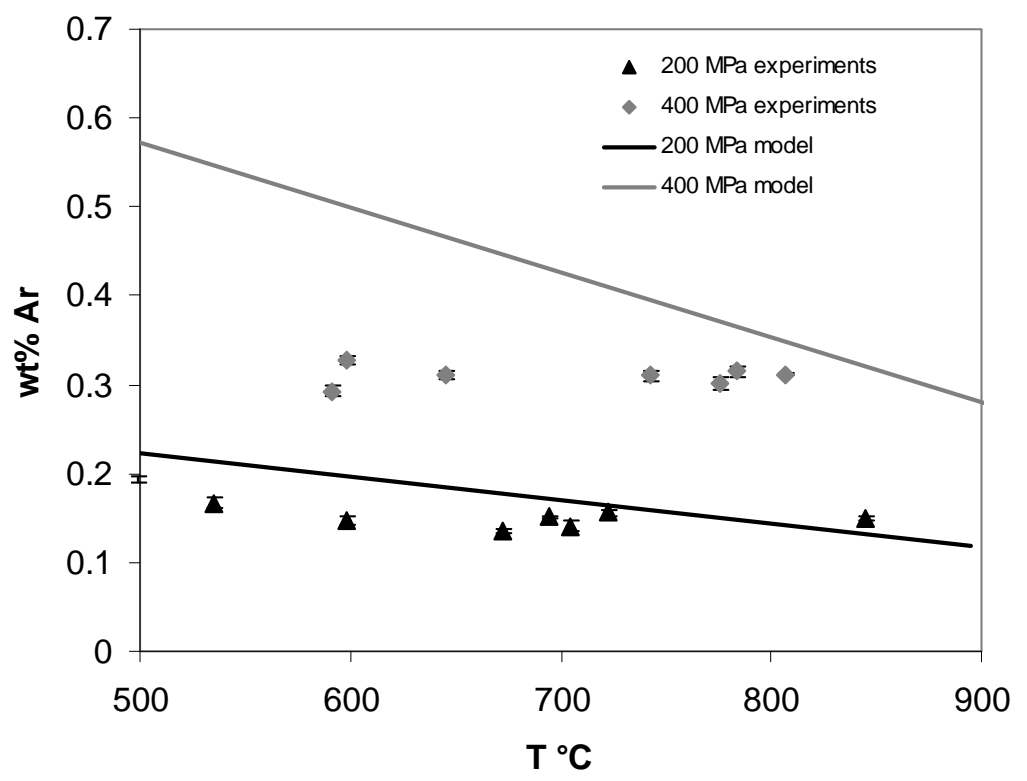

Fig. 9 

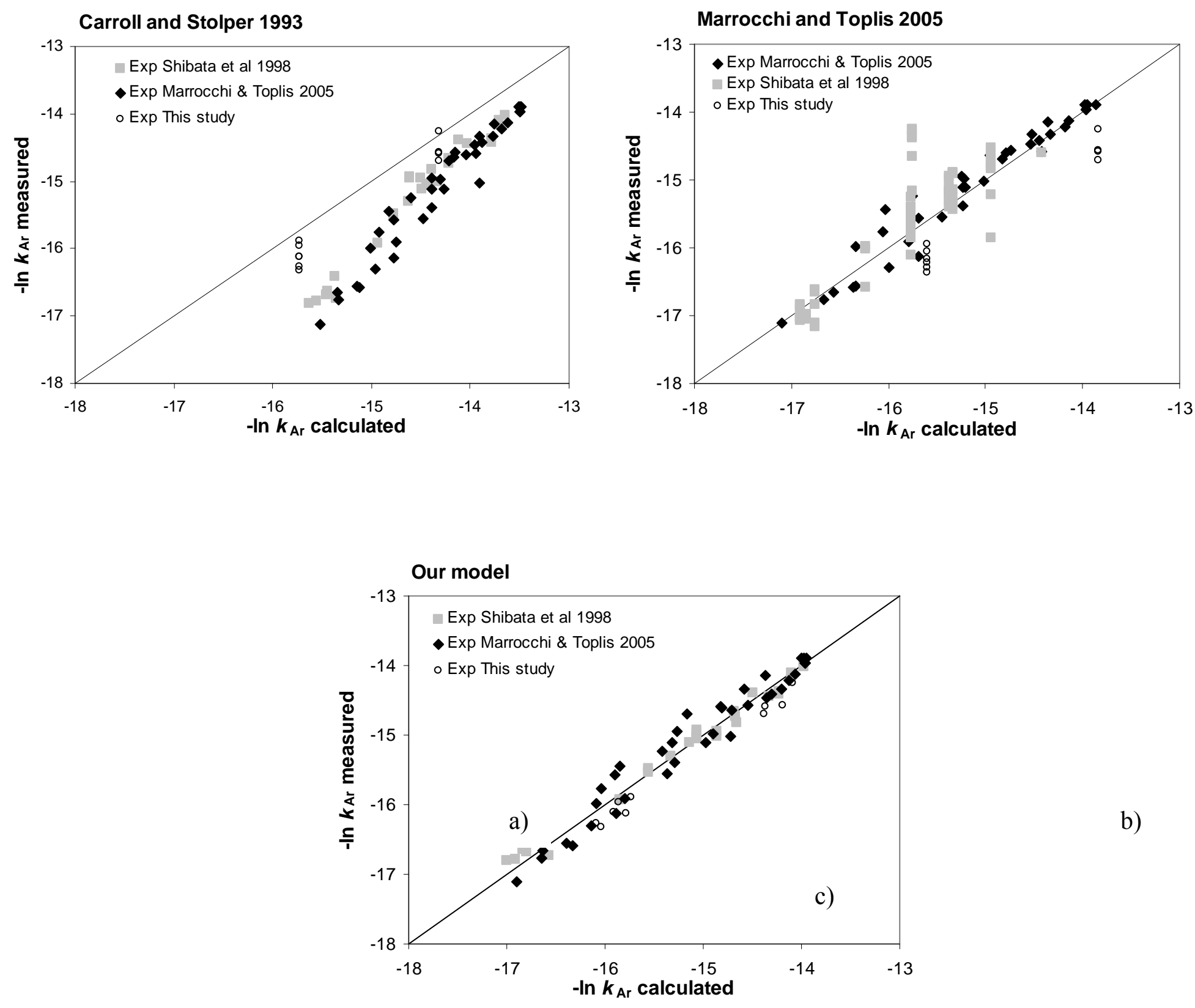

Fig.10 


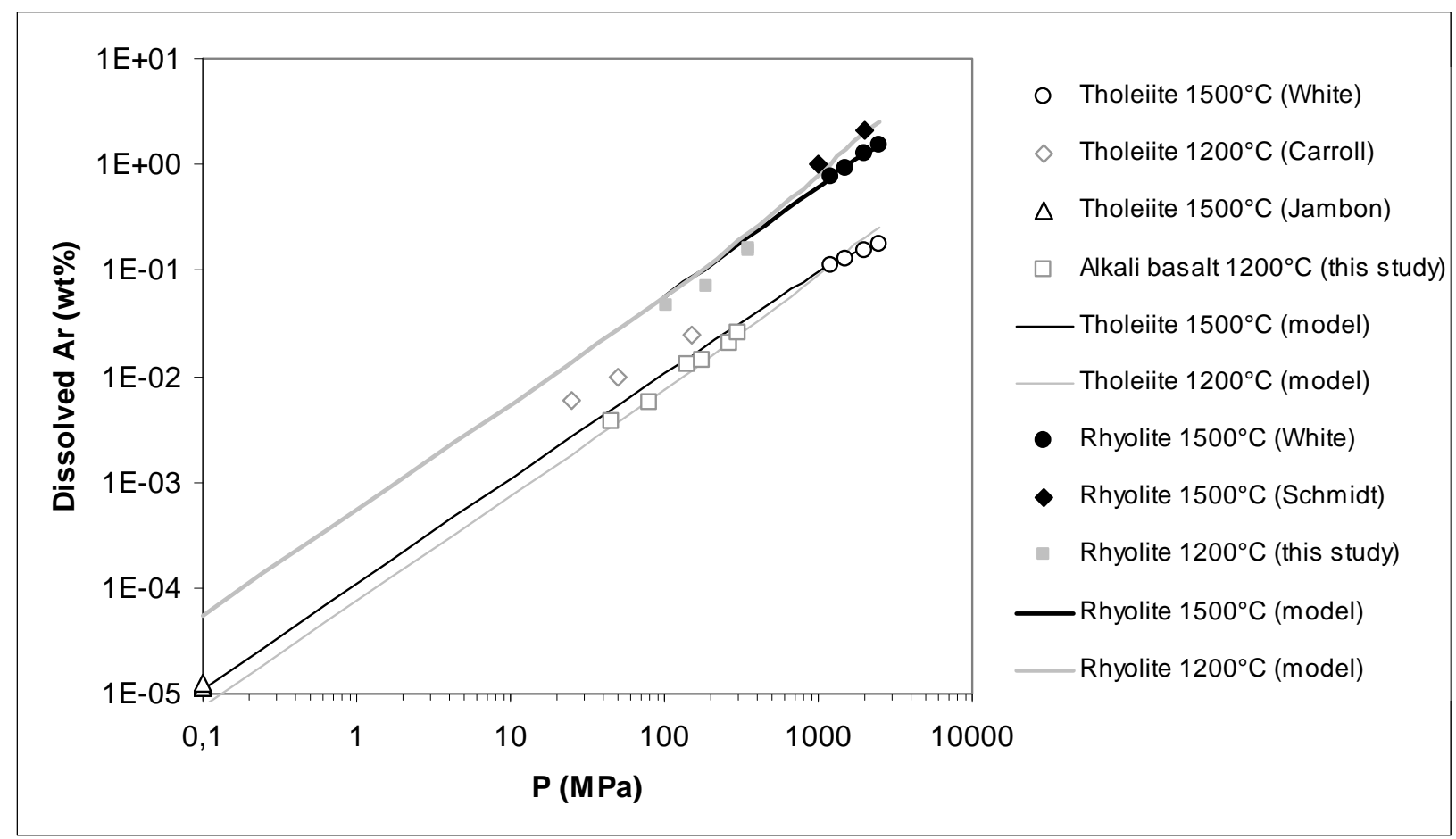

\section{Fig.11}




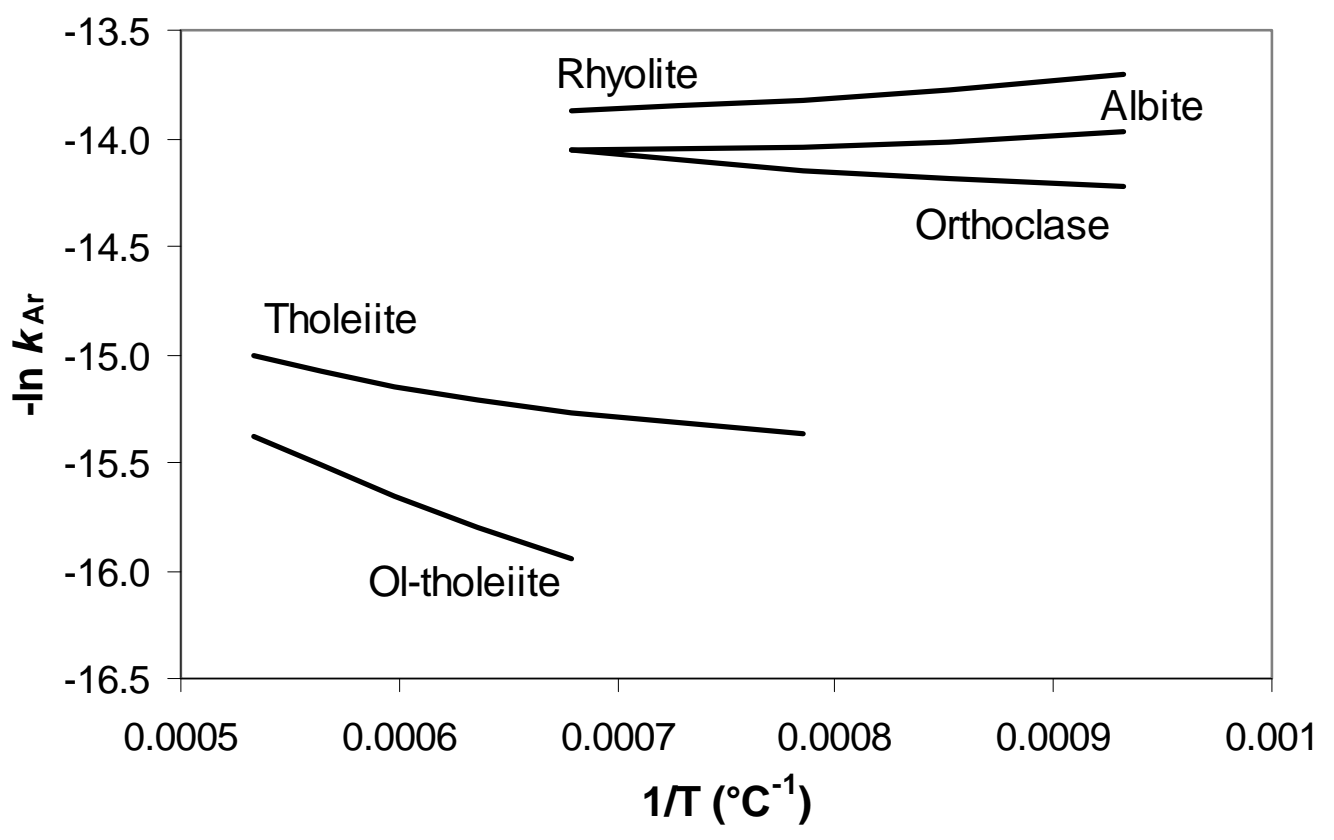

Fig.12 